\title{
The Separation of Voting and Control: The Role of Contract in Corporate Governance
}

\author{
Gabriel Rauterberg ${ }^{\dagger}$
}

The default rules of corporate law make shareholders' control rights a function of their voting power. Whether a director is elected or a merger is approved depends on how shareholders vote. Yet, in private corporations shareholders routinely alter their rights by contract. This phenomenon of shareholder agreements - contracts among the owners of a firmhas received far less attention than it deserves, mainly because detailed data about the actual contents of shareholder agreements has been lacking. Private companies disclose little, and shareholder agreements are thought to play a trivial or nonexistent role in public companies.

I show that this is false-fifteen percent of corporations that went public in recent years did so subject to a shareholder agreement. With this dataset in hand, I show the dramatic extent to which these shareholders redefine their control rights by contract. Shareholders restrict the sale of shares and waive aspects of the duty of loyalty. Above all, however, shareholders use their agreements to bargain with each other over votes for directors, and to bargain with the corporation itself for other control rights, such as vetoes over major corporate actions. In essence, while statutory corporate law makes control rights a function of voting power, shareholder agreements make control rights a function of contract instead, separating voting and control.

Studying this phenomenon raises new questions of doctrine, theory, and empirics that go to foundational issues in corporate law. Is it desirable to let shareholders redesign corporate control rights wholesale by contract? What law should govern their contracts when they do so? I provide a novel account of shareholder agreements' use in public firms, before offering preliminary views on their welfare effects, implications for corporate

$\dagger$ Assistant Professor of Law, University of Michigan Law School. I thank Robert Bartlett, Richard Brooks, Ryan Bubb, Tony Casey, Emiliano Catan, Albert Choi, Anne Choike, Patrick Corrigan, John Denniston, Jill Fisch, Jeffrey Gordon, Monica Hakimi, Henry Hansmann, Don Herzog, Jim Hines, Randy Holland, Marcel Kahan, Vikramaditya Khanna, Michael Klausner, Vice Chancellor Travis Laster, Kyle Logue, Elizabeth Pollman, J.J. Prescott, Roberta Romano, Sarath Sanga, Martin Schmalz, Stephen Davidoff Solomon, Holger Spamann, Richard Squire, Eric Talley, Andrew Verstein, and workshop participants at Iowa, Michigan, Notre Dame, Northwestern, NYU, Oxford, Wisconsin, CLAWS, and BYU Winter Deals for helpful comments. Nick Orr, Sarah Smith, Gabriel VanLoozen, Jenna Chen, Chase Glasser, and Megan Short provided exemplary research assistance. All errors are my own. 
theory, and on their governing law, which remains strikingly underdeveloped.

Introduction 1126

I. Shareholder Agreements and Corporate Governance

A. Instruments of Corporate Governance............................ 1131

B. Related Literature......................................................... 1133

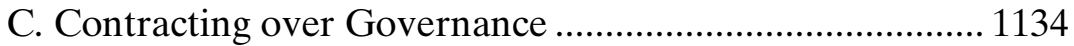

II. The Function of Shareholder Agreements................................ 1136

A. Procedural Differences.................................................... 1137

B. The Basic Statutory Allocation of Control Rights ........... 1138

C. The Separation of Voting and Control ............................ 1140

D. Contract and Consent..................................................... 1142

E. A Case Study in Separating Voting and Control: Control Sharing... 1144

F. Charters, Contracts, and Control Sharing ........................ 1146

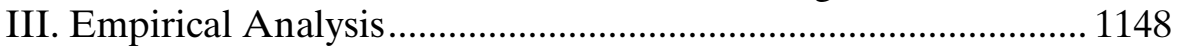

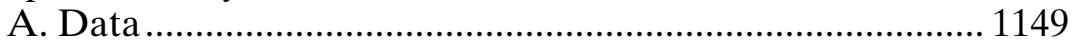

B. Shareholder Agreements in Practice............................... 1150

1. Characteristics of Adopting Firms ............................. 1152

C. Exploring Control Sharing Among Minority Investors ... 1154

IV. The Welfare Effects of Shareholder Agreements..................... 1158

A. Horizontal Shareholder Agreements............................... 1159

B. Vertical Shareholder Agreements................................... 1161

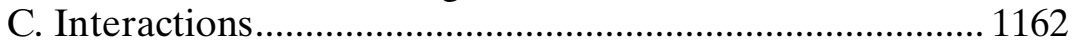

D. Controlling Minority Shareholders.................................. 1162

V. The Jurisprudence of Shareholder Agreements ......................... 1162

A. Vertical Commitments ...................................................... 1163

1. Corporate Commitments ............................................. 1163

2. How Many of Shareholders' Statutory Rights Can Shareholder Agreements Waive? ............................... 1166

B. Horizontal Commitments: Of Contract, Controlling Shareholders, and Fiduciary Duties.................................. 1167

1. Collective Controlling Shareholders ........................... 1168

VI. The Bigger Picture ...................................................................... 1171

A. What Is Control? .............................................................. 1171

B. What Is Public Company Governance? .......................... 1173

C. What Is Governance? ........................................................ 1174

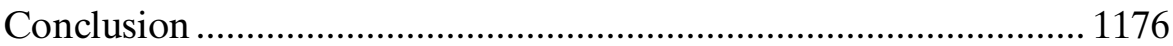


Introduction

Every year, some or all of a corporation's board of directors are up for election. Who serves on the board is decided by how the shareholders vote, and while usually sleepy affairs, contests for control of the board can make headlines and incur tens of millions of dollars in costs. ${ }^{1}$ But when Uber filed to go public in May 2019, it disclosed the distinctive way its current board of directors had been filled: a contract amongst its shareholders determined all twelve directors on the company's board. ${ }^{2}$ Elections brought no surprises. Major shareholders of Uber had agreed that each of them had the right to designate specific directors to the board, and then committed to vote for each other's designees. Because the signatories to the contract possessed a majority of Uber's voting power, their agreement ensured the election of their designees. The signatories included the major financial backers of Uber during its rise to prominence-such as investment firms Benchmark Capital, TPG, and SoftBank - as well as employees and founders, including the recently ousted CEO Travis Kalanick. Through their shareholder agreement, these parties, with their different and ultimately conflicting interests, had sustained for years an arrangement sharing control of the corporation with one another, each having secured representation on the board. With the closing of the initial public offering (IPO), its shareholder agreement terminated, and Uber began its life as a public company with the composition of its board left to the outcome of the annual election. ${ }^{3}$

Shareholder agreements - contracts among the owners of a firm and sometimes the firm itself-are a central instrument of corporate law and at the core of private company governance. ${ }^{4}$ Investors in private firms rely on these agreements to tailor the terms of ownership and to opt out of

1. See, e.g., David Benoit, P\&G vs. Nelson Peltz: The Most-Expensive Shareholder War Ever, WALL ST. J. (Oct. 6, 2017, 6:07 PM ET), https://www.wsj.com/articles/p-g-vs-nelson-peltzthe-most-expensive-shareholder-war-ever-1507327243 [https://perma.cc/CMA6-XHM6] (describing the $\$ 60$ million cost of the election contest for Proctor \& Gamble's board).

2. Uber Techs. Inc. Amendment No. 1 to Form S-1 Registration Statement 224 (Apr. 26, 2019).

3. With the closing of the IPO, its shareholder agreement terminated, and Uber began its life as a public company with the composition of its board left completely to the outcome of the annual election. Id. at 262 ("Upon the closing of this offering, the voting agreement will terminate and none of our stockholders will have any special rights regarding the election or designation of members of our board of directors.").

4. See, e.g., Corporate Law Committee of the Association of the Bar of the City of New York, The Enforceability and Effectiveness of Typical Shareholders Agreement Provisions, 65 BUS. LAW.1153,1155 (2010) [hereinafter Enforceability and Effectiveness] ("Agreements among two or more shareholders of a corporation are commonly used in connection with private equity and venture capital investments, joint ventures, and other corporate transactions."); see infra Section II.B. 
otherwise governing rules of law. ${ }^{5}$ And in recent years, their legal profile has dramatically expanded. Disputes involving shareholder agreements increasingly preoccupy the nation's preeminent corporate law courts in Delaware, where most large companies are incorporated. This culminated in a controversial Delaware Supreme Court decision in October of 2019 addressing whether the parties to a shareholder agreement together formed a controlling shareholder. ${ }^{6}$

Economists and legal scholars, however, have tended to overlook shareholder agreements. ${ }^{7}$ The answers to basic questions sometimes remain unknown and unasked, including how shareholder agreements' legal structure works and the nature of their governing jurisprudence. I offer a general theoretical, empirical, and doctrinal analysis of shareholder agreements.

The Article makes three principal contributions. First, I explain the distinctive legal role of shareholder agreements. After all, why use a contract to shape control rather than corporate law's basic instruments - the charter and bylaws? The answer, I argue, lies in both procedural and substantive differences between shareholder agreements and the corporate charter (or bylaws). Procedurally, both the charter and a shareholder agreement can be understood as different paradigms or recipes for how collective decision-making in a corporation occurs. How rights or duties are created and changed differs materially between the two instruments. To change the charter, the board of directors must initiate an amendment and a majority of shareholders (or more) must approve it in a vote of all shareholders. To change a shareholder agreement, there is neither a veto

5. See, e.g., 1 F. Hodge O'NeAl \& Robert B. Thompson, Close Corporations AND LLCs: LAW AND PRACTICE § 1:4, 1-14 (rev. 3d ed. 2004). Several model shareholder agreements exist for corporations to adopt. See, e.g., Voting Agreement, NAT'L VENTURE CAP. ASS'N (July 2020), https://nvca.org/-model-legal-documents [https://perma.cc/SNY2-MZDR] (click on "Voting Agreement" to download).

6. Sheldon v. Pinto Tech. Ventures, L.P., 220 A.3d 245, 251 (Del. Oct. 4, 2019) (holding that the signatories to a voting agreement did not constitute a control group). For other recent cases involving legal issues centered around shareholder agreements, see, for example, Arkansas Teacher Retirement System v. Alon USA Energy, Inc., No. CV 2017-0453-KSJM, 2019 WL 2714331 (Del. Ch. June 28, 2019); Manti Holdings, LLC v. Authentix Acquisition Co., C.A. No. 2017-0887-SG, 2018 WL 4698255 (Del. Ch. Oct. 1, 2018); In re Hansen Medical, Inc. Stockholders Litigation, No. 12316-VCMR, 2018 Del. Ch. LEXIS 197 (Ch. June 18, 2018); Schroeder v. Buhannic, C.A. No. 2017-0746-JTL (Del. Ch. 2017); OptimisCorp v. Waite, No. CV 8773-VCP, 2015 WL 5147038, at *74 (Del. Ch. Aug. 26, 2015), aff'd, 137 A.3d 970 (Del. 2016); Huff Energy Fund L.P. v. Gershen, C.A. No. 1116-VCS, 2016 WL 5462958 (Del. Ch. 2016); Caspian Select Credit Master Fund Ltd. v. Gohl, No. CV 10244-VCN, 2015 WL 5718592 (Del. Ch. Sept. 28, 2015); and Halpin v. Riverstone National, Inc., C.A. No. 9796-VCG, (Del. Ch. Feb. 26, 2015).

7. For a discussion of the related literature, especially in venture capital, see Section I.B. 
granted the board, nor a requirement that all shareholders vote or a majority approve. ${ }^{8}$

The substantive differences arise because corporate law empowers shareholders to personally waive certain rights by contract that the charter and bylaws cannot remove. ${ }^{9}$ Statutory rules that are mandatory for the charter and bylaws sometimes do not bind shareholder agreements. For instance, while corporate law's statutory rules tie control to voting power, shareholder agreements allow the separation of voting and control. In corporate democracy, the default system is voting. Statutory corporate law confers authority over corporate affairs on the board of directors and justifies that authority through the board's election by shareholders. ${ }^{10}$ That statutory system makes the election of the board a function of shareholder voting power. Even its most flexible default rules, such as class-specific voting rights, tether directorships to shareholders' votes. ${ }^{11}$ The control rights retained by shareholders as a default, such as approval of a merger or liquidation, likewise turn on how they vote. Shareholders, however, can alter these defaults by contract, and in private firms, do so widely. Shareholders, if they so desire, can bargain directly over directorships by contract.

Shareholder agreements can do this for reasons that lie in the governing case law. Under it, the limit of parties' freedom to design the corporate charter and bylaws is the capacious, but ultimately bounded statutory scheme contemplated by the Delaware General Corporation Law (DGCL). ${ }^{12}$ Shareholder agreements need not be so constrained; instead, they sometimes impose only the generic boundaries of freedom of contract - the public policy of the state, here Delaware..$^{13}$ Why this difference in treatment? As contracts, shareholder agreements are creatures of parties' actual consent and can only be changed with their consent. ${ }^{14}$ The charter and bylaws, in contrast, can be altered by collective decision-making that nonconsensually subordinates a specific shareholder's rights. The

8. While these differences are fundamental, this Article emphasizes the substantive differences. In future work, I intend to explore the normative propriety of shareholder contracting by focusing precisely on these broadly procedural differences.

9. See infra Section II.B.

10. See, e.g., In re CNX Gas Corp. S'holders Litig., No. 5377-VCL, 2010 WL 2291842, at *15 (Del. Ch. May 25, 2010) ("[D]irector primacy remains the centerpiece of Delaware law ...."); Blasius Indus., Inc. v. Atlas Corp., 564 A.2d 651, 659 (Del. Ch. 1988) ("The shareholder franchise is the ideological underpinning upon which the legitimacy of directorial power rests.").

11. I explore in depth the contrast between using a corporate charter and shareholder contract to achieve similar ambitions in infra Section II.C.

12. See infra Section II.C.

13. See infra Section II.B. In particular, case law shows that while the charter cannot abrogate shareholders' removal power, they can unilaterally waive it. See Section V.A.

14. The parties to a contract can of course choose a different rule to govern subsequent changes to the contract. 
Delaware courts take the difference seriously: there are rights that cannot be taken from a shareholder, but which he or she can personally waive.

But why do shareholders value the ability to contractually bargain with each other over directorships? One key reason is that by allowing minority shareholders to contract for board seats, shareholder agreements facilitate control sharing - a broad class of governance arrangements in which minority shareholders participate actively in controlling a corporation's affairs. ${ }^{15}$ The venture capital and private equity literature have extensively explored such control sharing in private companies. ${ }^{16}$

The second contribution of the Article is empirical. To the extent that one exists, the conventional wisdom about shareholder agreements is that they are common in private companies, but private companies are the dark matter of the corporate universe-important, but challenging to study empirically. They are not required to publicly disclose any instrument of governance beyond filing their charter with the Secretary of State. In public companies, shareholder agreements are thought to play a trivial or nonexistent role. ${ }^{17}$ The attraction of this view is obvious-how could the dispersed shareholders of a public corporation ever actually enter a contract with one another, and what use would a controlling shareholder find in entering such an agreement with the company alone?

This view, it turns out, is false. I show that about fifteen percent of companies that go public over the last six years do so subject to a shareholder agreement. ${ }^{18}$ Through these agreements, shareholders broadly transform their rights. They routinely contract over the composition of the

15. See infra Section II.B. My contention is not that shareholder agreements are the only legal device that can facilitate control sharing. I look at potential substitutes in Section II.C. My argument is only that facilitating control sharing is the distinctive role of shareholder agreements, and that partial substitutes are only that-importantly partial. They cannot achieve all of the same ends as shareholder agreements, and they impose a distinct profile of costs that shareholder agreements do not.

16. See, e.g., Robert P. Bartlett, III, Shareholder Wealth Maximization as Means to an End, 38 Seattle U. L. ReV. 255 (2015); Steven N. Kaplan \& Per Strömberg, Financial Contracting Theory Meets the Real World: An Empirical Analysis of Venture Capital Contracts, 70 ReV. ECON. STUD. 281, 288 (2003); Elizabeth Pollman, Startup Governance, 168 U. PA. L. REV. 155, 221 (2019); D. Gordon Smith, The Exit Structure of Venture Capital, 53 UCLA L. REV. 315 (2005).

17. See, e.g., Steven N. Bulloch, Shareholder Agreements in Closely Held Corporations: Is Sterilization an Issue?, 59 TEMP. L.Q. 61, 62 (1986) ("Shareholder agreements are almost always made by participants in closely held rather than publicly held corporations."); Suren Gomtsian, The Governance of Publicly Traded Limited Liability Companies, 40 DEL. J. CORP. L. 207, 229 (2015) ("[U]nlike U.S. listed corporations, shareholders agreements seem to be practiced in publicly traded LLCs."); Marco Ventoruzzo, Why Shareholders'Agreements Are Not Used in U.S. Listed Corporations: A Conundrum in Search of an Explanation 1 (Pa. State Univ. Dickinson Sch. of L., Bocconi Legal Studies Research Paper No. 42-2013, 2013), https://ssrn.com/abstract=2246005 [https://perma.cc/E9WM-L5KG] ("[O]ne of the most puzzling and overlooked issues of US corporate law and securities regulation ... is why agreements among shareholders are not often used ....")

18. See infra Section III.B. 
board of directors. The vast majority of the agreements grant specific shareholders board nomination rights, and more than half of them include a contract to vote in specific ways among some or all of the agreement's parties. The agreements are also used to form contracts between shareholders and the corporation itself. In a substantial minority of agreements, the corporation grants specific shareholders veto rights over major corporate decisions, such as mergers, terminating the $\mathrm{CEO}$, or changing lines of business. Other agreements waive the corporate opportunity doctrine, restrict the transferability of shares in any number of ways, or mandate arbitration of claims. Most surprisingly, in a majority of agreements, the corporation commits to supporting specific shareholders' board nominees by including the nominees in the corporate proxy slate and using its best efforts to ensure the nominees' election. ${ }^{19}$

The third contribution is to map out the conceptual features of postIPO shareholder agreements and the novel legal issues they raise. One can usefully separate these contractual commitments into "horizontal" and "vertical" dimensions, where the horizontal dimension refers to commitments among shareholders, and the vertical dimension refers to commitments between the corporation and one or more shareholders. ${ }^{20}$ The commitments by shareholders to vote for each other's nominees are horizontal commitments, while promises by the corporation to support those nominees, corporate grants of veto rights to shareholders, or commitments by shareholders to the corporation to waive rights they could otherwise exercise are all vertical commitments. Each kind of commitment raises distinct legal issues, and the vertical commitments by corporations raise enforceability issues that other provisions typically do not. ${ }^{21}$ Surprisingly, however, even the basic law of shareholder agreements remains strikingly underdeveloped with major questions left open, including the legality of common provisions, the relationship between voting agreements and fiduciary duties, and principled limits on what rights shareholders may waive by contract.

This Article thus explains how shareholder agreements are used to assign all manner of control rights directly in a set of new public companies.

19. See infra Sections III.B, III.C, and III.D. Another forty percent of companies going public disclose that they had been subject to a shareholder agreement but that such agreement terminates as of the IPO. These agreements contain many of the provisions discussed above, but typically impose more dramatic transfer restrictions and voting agreements.

20. The extensive use of vertical commitments may be where post-IPO agreements most vividly diverge from the model shareholder agreements of private, venture-backed firms, where those commitments are typically placed in the corporate charter. See also infra Section II.B; cf. Voting Agreement, supra note 5. As I discuss later, however, the set of shareholder agreements I observe could be in part a function of public company disclosure rules.

21. In particular, the vertical commitments raise doctrinal and normative questions about the appropriate role of shareholders and directors in corporate governance. See infra Part VI. They also mean that post-IPO shareholder agreements involve control sharing on two distinct levels - among shareholders in securing board representation, and between shareholders and the board in control over material decisions the corporation must make. 
This explanatory and empirical account has normative implications for some of corporate law's most foundational debates. For instance, understanding these shareholder agreements calls into question two central distinctions in corporate law - that control over the board should be accompanied by fiduciary duties, while the exercise of mere contractual rights should not, and that public shareholders bargain for discretionary "residual rights of control," while other stakeholders, like creditors, protect themselves by contract.

Shareholders' extensive use of contractual rights forces us to revisit the nature of control along both fronts. It also raises the fundamental normative question of whether it is desirable for shareholders to be able to contractually reallocate control rights that are otherwise tied to the ownership of shares and defined by the corporate charter.

The Article proceeds as follows. In Part I, I briefly explain the instruments of corporate governance, the related literature, and offer an illustrative agreement. In Part II, I outline a framework for understanding shareholder agreements' distinctive role in corporate law and governance. In Part III, I present the universe of agreements I study and explore their function. In Parts IV, V, and VI, I survey implications, offering preliminary views on the welfare effects of shareholder agreements (IV), the rich set of legal issues they raise (V), and their implications for broader debates in corporate law (VI).

\section{Shareholder Agreements and Corporate Governance}

In this Part, I outline the main instruments of corporate governance, the related literature on shareholder agreements, and offer an illustration of one.

\section{A. Instruments of Corporate Governance}

Shareholder agreements occupy a particular place within corporate governance, and an overview of corporate law's more familiar instruments may be useful. ${ }^{22}$ The certificate of incorporation or "charter" is the foundational document of governance. ${ }^{23}$ A corporation must also have a bylaws, which is a more process-oriented document that addresses topics such

22. I will largely treat state corporate law issues as being about Delaware law because the vast majority of large companies are incorporated in Delaware, making it the de facto national corporate law of the United States. I will sometimes refer to the Model Business Corporation Act (MBCA), the second most prominent source of corporate law (as variously adopted by dozens of states) in the footnotes. See MOdEl Bus. CORP. ACT (AM. BAR Ass'N 2017).

23. Every corporation must file a charter with the Secretary of State to be legally formed (or "incorporated"). The charter must contain a small number of provisions, including the definition of a corporation's stock and the powers, preferences, and rights of each class of stock. DEL. CODE ANN. tit. 8, § 102(a) (2020). 
as when board meetings must be held, how large the board will be, its committees, and the like. ${ }^{24} \mathrm{~A}$ corporation need not be subject to a shareholder agreement, although it is widely noted that many private corporations are subject to one..$^{25}$

Significant differences exist among the charter, bylaws, and shareholder agreements concerning their broadly "procedural" attributes, such as who can amend them, when, and how. The charter can be amended only if both the board and a majority of shareholders vote to approve the amendment. ${ }^{26}$ Typically, either the board or a majority of shareholders can unilaterally amend the bylaws. ${ }^{27} \mathrm{By}$ contrast, the shareholder agreement is a contract, and thus (at least as a default) is governed by contract law's rules. Accordingly, the agreement can be amended if and only if all of its signatories consent, unless they adopt an alternative rule. ${ }^{28}$ Action by the board, such as a board resolution, can be done whenever the board so wishes.

24. DEL. CODE ANN. tit. 8, § 109(a) (2020). There are no mandatory terms for the bylaws, and they can contain any provision consistent with the charter so long as they do not "impose liability on a stockholder for the attorneys' fees or expenses of the corporation or any other party in connection with an internal corporate claim, as defined in $\S 115$ of this title." Id. § 109(a)-(b).

25. Bulloch, supra note 17, at 62 ("Shareholder agreements are almost always made by participants in closely held rather than publicly held corporations."); Mark R. High, Drafting BuySell Provisions in Shareholder Agreements: Can We "Insure" Compliance?, Bus. L. TODAY, May-June 2010, at 59, 62 ("Shareholder agreements are among the most common, and most critical, documents that are in a close corporation's files."); Brett H. McDonnell, Sticky Defaults and Altering Rules in Corporate Law, 60 SMU L. REV. 383, 406 n.136 (2007) ("A shareholder agreement is a common method of structuring shareholder relationships within the corporation in closely held corporations."). Scholarly and practitioner commentary on shareholder agreements overwhelmingly focuses on their role in private corporations. See generally Enforceability and Effectiveness, supra note 4; Wulf A. Kaal, United States of America (National Report), in INTERNATIONAL HANDBOOK ON SHAREHOLDERS' AGREEMENTS (Kristian Csach, Bohumil Havel \& Sebastian Mock eds., 2018).

26. More precisely, the incorporators of a corporation-usually its founders or their attorneys - draft the original charter, DEL. CODE ANN. tit. 8, § 103(a)(1) (2020), but once a corporation has received any payment for its shares, Delaware imposes a demanding rule for any subsequent changes to the charter: the board must adopt a resolution setting forth the proposed amendment, and a majority of the stock entitled to vote must vote in favor of the amendment. DEL, CODE ANN. tit. 8, § 242(b)(1) (2020).

27. Again, to be precise, the incorporators of a corporation, or its original board of directors, can adopt and amend the original bylaws. DEL. CODE ANN. tit. 8, § 109(a) (2020). However, once the corporation has received any payment for its stock, then new bylaws can be adopted and standing bylaws amended only by a shareholder vote. Id. A corporation can also confer the power to adopt and repeal bylaws upon the board of directors in its charter, and corporations overwhelmingly do this. In effect, then, both the shareholders and board can unilaterally amend bylaws in most corporations, although the actual capacity of shareholders to do so in a public corporation is far more limited than the ability of the directors to do so. See Jill E. Fisch, Governance by Contract: The Implications for Corporate Bylaws, 106 CALIF. L. REV. 373, 382-99 (2018).

28. See, e.g., Blount v. Taft, 225 S.E.2d 583, 586 (N.C. Ct. App. 1976) ("A shareholders' agreement may not be altered or terminated except as provided by the agreement, or by all parties ...."). 
Yet while the charter and bylaws have been the subject of illuminating study, ${ }^{29}$ far less attention has been dedicated to the distinctive legal character of shareholder agreements. I address the related literature in the next section.

\section{B. Related Literature}

Empirical study of shareholder agreements in the United States is limited. ${ }^{30}$ The only empirical scholarship I know of directly addressing shareholder agreements in U.S. public firms is a Brazilian study that compares shareholder agreements entered by 54 Brazilian public companies and 65 U.S. ones between 2010 and 2012 and emphasizes the lack of stylistic differences between the two and their different methods of dispute resolution..$^{31}$ Accounting Professor Jordan Schoenfeld insightfully studies a large universe of bilateral contracts between individual shareholders and corporations that accompany $13 \mathrm{D}$ investments. ${ }^{32}$

Legal scholarship on shareholder agreements' role in private companies, on the other hand, dates back at least a century. ${ }^{33}$ In particular, many commentators on the "close corporation" have observed how shareholders use contracts to structure their affairs together. ${ }^{34}$ In other private company contexts, the pivotal role of shareholder agreements is similarly well-

29. For seminal work on corporate charters, see, for example, Roberta Romano, Law as a Product: Some Pieces of the Incorporation Puzzle, 1 J.L. ECON. \& ORG. 225 (1985); and Robert Daines \& Michael Klausner, Do IPO Charters Maximize Firm Value? Antitakeover Protection in IPOs, 17 J.L. ECON. \& ORG. 83 (2001). For important work on bylaws, see, for example, Albert H. Choi \& Geeyoung Min, Contractarian Theory and Unilateral Bylaw Amendments, 104 IowA L. REV. 1, 4 (2018); and Jill E. Fisch, The New Governance and the Challenge of Litigation Bylaws, 81 BROOK. L. REV. 1637 (2016).

30. See, e.g., Ventoruzzo, supra note 17 (seeking to explain why U.S. public companies do not use shareholder agreements).

31. Helena Masullo, Shareholder Agreements in Publicly Traded Companies: A Comparison Between the US and Brazil, 12 BRAZ. J. INT'L L. 402 (2015). Masullo's analysis notes that shareholders enter voting agreements over directorships and restrict the transferability of shares.

32. Schoenfeld's important paper studies the bilateral contracts that large shareholders enter with public corporations in connection with block investments and finds that thousands of block investments are accompanied by such bilateral contracts. See Jordan Schoenfeld, Contracts Between Firms and Shareholders, 58 J. ACCT. RES. 383 (2020). While "shareholder agreements" as usually contemplated by legal scholarship involve multiple shareholders, there is intriguing overlap between many of the provisions Schoenfeld studies and those analyzed here. Schoenfeld also offers an illuminating analysis of whether shareholder-manager contracts may serve to reduce managerial agency problems. Id.

33. Jesse W. Lilienthal, Corporate Voting and Public Policy, 10 HARV. L. REV. 428, 433 (1897) (discussing voting agreements). Jill Fisch vigorously criticizes the wide scope that shareholder agreements in large corporations provide for private ordering. Jill E. Fisch, Private Ordering and the Role of Shareholder Agreements, 99 WASH. U. L. REV. (forthcoming 2022).

34. George D. Hornstein, Stockholders' Agreements in the Closely Held Corporation, 59 YALE L.J. 1040 (1950). For more recent treatment, see O'NEAL \& THOMPSON, supra note 5, $\S 5$; Kerry M. Lavalle, Drafting Shareholder Agreements for the Closely-Held Business, 4 DePaul Bus. L.J. 109 (1991); and Robert B. Thompson, The Law's Limits on Contracts in a Corporation, 15 J. CORP. L. 377 (1990). 
appreciated. For instance, in venture capital and private equity financing, shareholder agreements are pervasively used, typically in combination with class-specific charter arrangements, to facilitate the sharing of control among distinct investors. ${ }^{35}$ Indeed, a large body of empirical work on venture-backed private companies explores the governance of those firms and the nature of their control rights. ${ }^{36}$ Practitioner commentary on the governance structures of post-IPO firms also insightfully refers to the role of shareholder agreements. ${ }^{37}$

Further, the function of shareholder agreements, such as their ability to contractualize the composition of the board, relates closely to themes in the far larger literatures around the governance of venture capital-backed private companies, the governance of private equity portfolio companies, the role of share transfer restrictions, creditor control rights, and others..$^{38}$ The question remains, however, of what explains the relative neglect of shareholder agreements. At least two reasons are worth remembering. First, the lack of an empirical foundation meant that interesting conceptual questions felt unmotivated or baseless. Second, historically, there has been a tendency to homogenize the charter, bylaws, and shareholder agreement into a uniform category of "contract" that ignores the many and important differences among them.

\section{Contracting over Governance}

Legal scholars have emphasized that corporate law grants the owners of corporations three fundamental kinds of rights: exit, voice, and liability - the rights to sell your shares, to vote in elections of the board of

35. See, e.g., WILLIAM CARNEY, ROBERT BARTLETT III \& GEORGE GEIS, CORPORATE FINANCE: PRINCIPLES AND PRACTICE 566 (4th ed. 2019); see also Voting Agreement, supra note $5, \S 1.2$ (discussing voting agreement and its relation to charter-based director designation rights); Certificate of Incorporation, NAT'L VENTURE CAP. Ass'N, at art. IV, § B, cl. 3 (Sept. 2020), https://nvca.org/-model-legal-documents [https://perma.cc/G866-T59S] (discussing the election of directors and its allocation across charter classes by class-specific voting rights). For an illuminating discussion of why venture capital-backed companies choose the corporate form in the first place, see Gregg D. Polsky, Explaining Choice-of-Entity Decisions by Silicon Valley Start-Ups, 70 HASTINGS L.J. 409 (2019). The venture capital literature has extensively explored the allocation of control among shareholders and the use of shareholder agreements while typically not making the agreements themselves a direct object of study. See, e.g., Brian J. Broughman, The Role of Independent Directors in Startup Firms, 2010 UTAH L. REV. 461, 468 (noting that in private firms parties routinely define the allocation of board seats in the charter and voting agreements).

36. Kaplan \& Strömberg, supra note 16, at 288. For recent empirical work, see, for example, Michael Ewens, Alex Gorbenko \& Arthur Korteweg, Venture Capital Contracts (Dec. 2020) (unpublished manuscript), https://ssrn.com/abstract=3423155 [https://perma.cc/SGL3KF5U].

37. See, e.g., Douglas P. Warner et al., A Look at Governance and Liquidity Arrangements in Sponsor-Backed Initial Public Offerings, WeIL: GLOBAL PE WATCH (2017), https://privateequity.weil.com/whats-market/a-look-at-governance-and-liquidity-arrangements-in-2019sponsor-backed-initial-public-offerings [https://perma.cc/8XK2-BJPB].

38. See infra notes $81,85,117,161$, and accompanying text. 
directors, and to sue disloyal executives. ${ }^{39}$ Under Delaware's default rules, shareholders can freely sell their shares ${ }^{40}$ vote in elections of the board of directors and on certain fundamental transactions, ${ }^{41}$ and can sue the officers and directors for violating the fiduciary duties of loyalty and care.

The agreements I explore alter shareholders' rights along each of these dimensions. To preview, they commonly grant shareholders the right to nominate directors to the board and render that right effective through voting agreements among shareholders who commit to vote for each other's nominees. They grant specific parties-sometimes minority shareholders - veto rights over a range of major corporate policy decisions, such as whether to fire the CEO, effect a change of control, or change lines of business. They waive major shareholders' obligations to present corporate opportunities to the firm, which the fiduciary duty of loyalty would otherwise require, and they sometimes, though more rarely, restrict the ability of shareholders to sell their shares through tag-along rights (granting one party the right to sell their stock to a bidder on the same terms the other party is being offered), drag-along rights (obligating one party to sell their stock if another party chooses to), and other transfer restrictions. ${ }^{42}$

As an illustration of an agreement, consider GoDaddy, Inc. GoDaddy is the world's largest host for websites, and more broadly, a global leader for providing cloud services to small businesses. The company went public on April 1, 2015, and filed its stockholders agreement with the SEC shortly beforehand. ${ }^{43}$ The parties included GoDaddy itself, the private equity firms Kohlberg Kravis Roberts \& Co. (KKR), Silver Lake Partners, and Crossover Ventures (all major pre-IPO investors in GoDaddy), and Bob Parsons, the founder of the company. The agreement alters legal defaults along a broad variety of dimensions. In terms of governance, the agreement creates a board with nine directors and then grants to KKR and Silver Lake each the right to nominate two directors to the board (as long as they own over ten percent of the company's stock) ${ }^{44}$ and to Parsons the right to nominate one director (provided he owns five percent or more). ${ }^{45}$ GoDaddy itself commits to support the nominees' election by including them

39. Albert O. Hirschman, Exit, Voice, And loyalty: Responses to DeCline In Firms, ORganizations, AND STATES (1970); Henry Hansmann \& Reinier Kraakman, Exit, Voice and Liability: The Dimensions of Organizational Structure (2008) (unpublished manuscript), https://papers.sioe.org/paper/131.html [https://perma.cc/M376-K3D9].

40. DEL. CODE ANN. tit. 8, § $202(2020)$.

41. See, e.g., DEL. CODE ANN. tit. 8, §§ 141(k), 251 (2020).

42. Other common restrictions include granting a party a right of first refusal (where one party cannot sell its stock without first offering it to the party possessing the right of first refusal), although a range of more involved options also exist.

43. See Stockholder Agreement by and Among GoDaddy Inc., Desert Newco, LLC, and the Other Parties Named Herein (Form S-1, ex. 10.3) (Mar. 31, 2015).

44. Id. $\$ 2.1(\mathrm{~b})(\mathrm{i})$-(ii).

45. Id. $\$ 2.1(\mathrm{~b})(\mathrm{iii})$. 
in its proxy statement and preferred slate, and to "otherwise use its reasonable best efforts to cause such nominees to be elected to the board." ${ }^{46} \mathrm{Sim}$ ilarly, each of the shareholder parties commits to vote for the other's nominees. ${ }^{47}$

The agreement also requires each of Silver Lake and KKR's approval if GoDaddy wishes to engage in any one of several important decisions, including a change in control, a material change in its line of business, and the termination of its $\mathrm{CEO} .{ }^{48}$ The shareholder parties agree, with few exceptions, to not sell any of their securities for three years without the consent of both KKR and Silver Lake. ${ }^{49}$ Lastly, the agreement waives the company's right to any business opportunities encountered by the private equity firms' director nominees. ${ }^{50}$ The agreement thus reconfigures Delaware's longstanding defaults along each of exit, voice, and liability.

It is worth stating a puzzle here. Much of what is described above can also be done through the charter or bylaws. In fact, some of these provisions, such as waivers of the corporate opportunity doctrine, seem to occur more commonly in the charter than in a shareholder agreement. ${ }^{51}$ The puzzle is why fundamental features of corporate governance are ever established through contracts among investors - shareholder agreements-rather than the charter or bylaws. The charter and bylaws are not only the more familiar forms of governance; the charter offers conspicuous advantages as well because courts treat charter provisions with greater deference than other instruments. Why do shareholder agreements exist, and are there substantive ambitions of corporate governance that they can distinctively promote? In Part II, I turn to that issue and argue for an affirmative answer to the latter question.

\section{The Function of Shareholder Agreements}

In this Part, I explain why shareholders would seek to create and change important control rights by contract rather than by the corporate charter (or bylaws). Broadly, the reasons are both procedural and

\footnotetext{
46. Id. § 2.1(b)(iv).

47. Id. $\$ 2.3$.

48. Id. $\$ 3.6$.

49. Id. § 3.9. The working of this restriction, like most of the other transfer restrictions, is truly byzantine.

50. Id. § 3.4. More precisely, the agreement "contain(s) a covenant that requires our amended and restated certificate of incorporation to provide for a renunciation of corporate opportunities presented to KKR, Silver Lake, TCV, Mr. Parsons and their respective affiliates and the KKR Directors, the Silver Lake Directors, the Parsons Director and any director affiliated with TCV to the maximum extent permitted by Section 122(17) of the DGCL." GoDaddy Prospectus (filed pursuant to Rule 424(b)(4)) (Mar. 31, 2015).

51. See Gabriel Rauterberg \& Eric Talley, Contracting out of the Fiduciary Duty of Loyalty: An Empirical Analysis of Corporate Opportunity Waivers, 117 COLUM. L. REV. 1075, 1125 (2017) (finding that the majority of waivers of the corporate opportunity doctrine are found in the charter).
} 
substantive. By procedural, I mean that both the charter and contract can usefully be conceived of as recipes for collective decision-making in organizations. They are both ways in which groups can determine their basic rights. Often, either contract or the charter could be used to achieve a similar substantive ambition. But they differ in how those substantive decisions are made. As is often true, these differences of process influence differences of substance too.

There are also profound substantive differences in what parties can directly do by contract and by charter, and I particularly develop one such difference in this Part: Statutory corporate law establishes a system in which the ability to elect directors is a function of the voting power shareholders possess. Shareholder agreements empower shareholders to instead make the election of directors a function of their contractual agreements. I call this "the separation of voting and control." 52 I briefly outline the default voting system contemplated by statutory corporate law and then explain how Delaware's courts have held that this system sets the bounds of experimentation for the charter and bylaws. Shareholder agreements are not so limited - they afford far greater flexibility to define how directors will be elected. I also explain why the courts have come to this conclusion. While the logic is subtly buried in the case law, it is profound.

\section{A. Procedural Differences}

When shareholders want to design basic features of corporate governance, they can turn to corporate law's foundational instrument, the corporate charter, or turn to contract law, and contract among themselves instead. The charter and contract can both be envisioned as processes through which corporate governance is created and changed. But they offer materially different paradigms for how collective decision-making is structured.

The recipe for amending the corporate charter will be familiar to any student of business organizations. To change the charter, the board of directors must adopt a resolution setting forth the amendment, and a majority of all outstanding stock must affirmatively vote to approve it. ${ }^{53} \mathrm{~A}$ corporation can make it harder to amend the charter by, say, demanding super-majority approval for any amendment, but the process above is a mandatory floor. The process required to change a contract, like a shareholder agreement, depends on whether the agreement adopts a specific rule for how it may be amended. Contract law's default is unanimity: all

52. The phrase is meant to evoke not only Berle and Mean's famous "separation of ownership and control," but also John Morley's observation that investment fund structure is defined by the separation of funds and managers. See AdOLF A. BERLE \& GARDINER C. MEANS, THE MODERn CORPORATION AND PRIVATE PROPERTY (1932); John Morley, The Separation of Funds and Managers, 123 YALE L.J. 1118 (2014).

53. DEL. CODE ANN. tit. 8, § 242(b)(1) (2020). 
parties must consent for the contract to be changed. These differences are important for far too many reasons to do justice to in this Article. But I will just gesture at a few.

Corporate law's mandatory process for altering governance effectively grants a veto to the board of directors over changes to the fundamentals of governance enshrined in the charter. If the board was just a function of the sentiments of a majority of voting power, this would matter little (and perhaps be redundant). The board, however, is subject to its fiduciary duties of loyalty and care that make it a locus of independent fidelities to the corporation and its shareholders as a whole. Less idealistically, the board is also a potential locus of agency costs. This means that the board may be a friction, for both good and ill, on majority shareholder sentiment.

I will end with a second difference. Changing the charter necessarily involves a vote of all shareholders and majority support at a minimum. A shareholder agreement need only involve a subset, perhaps a small one, of all shareholders.

\section{B. The Basic Statutory Allocation of Control Rights}

Delaware's statutory corporate law envisions a corporation that is controlled by a board of directors, but in which shareholders retain certain fundamental control rights. ${ }^{54}$ Perhaps most important are shareholders' right to elect directors and to approve specific material transactions. ${ }^{55}$ These basic rights turn on shareholders' voting power, as I will briefly discuss.

Statutory law creates default rules for how directors are elected and then creates specific ways in which those default rules may be altered. As a default, the entire board of directors is up for election each year and an election is won by the candidate who receives the most votes. ${ }^{56} \mathrm{~A}$ corporation can replace this plurality standard with one requiring a candidate to receive a majority of votes cast to win election, and most of the largest public corporations have adopted some form of majority vote. ${ }^{57}$ Whatever

54. DEL. CODE ANN. tit. $8, \S 141$ (a) (2020) ("The business and affairs of every corporation ... shall be managed by or under the direction of a board of directors"); § 141(d); § 141(k).

55. See, e.g., DEL. CODE ANN. tit. 8, § 211 (2020) (outlining basic default rules for corporate voting); $\$ 242$ (shareholder vote on charter amendments); $\$ 251$ (shareholder vote on mergers); $\$ 275$ (shareholder vote on sale of all or substantially all assets); $\$ 275$ (shareholder vote on dissolution). This is of course not exhaustive (shareholders also vote on proxy proposals, "say on pay," etc.). Shareholders also have myriad nonvoting rights that go to their control, from books and records requests to the indirect control offered by the protection of fiduciary duties.

56. DEL. CODE ANN. tit. 8, § 141(d) (2020).

57. See Stephen J. Choi et al., Does Majority Voting Improve Board Accountability?, 83 U. CHI. L. REV. 1119, 1121 (2016). 
the standard, holding a majority of voting power will ensure a favored candidate wins election.

These default rules can be altered in familiar ways authorized by statute. Annual elections can be replaced by a staggered board in which only a tranche of the board is up for election each year. ${ }^{58}$ Corporations may also alter the default rule of all directors being elected by the same class of common stock. A corporation may issue multiple classes of stock with different rights and privileges, including rights to elect specific directors, but each director must still be elected by a majority of voting power within that class of stock..$^{59}$ The last important statutory exception is cumulative voting..$^{60}$ If a corporation adopts cumulative voting then shareholders receive a number of votes equal to the product of their voting shares and the number of open directorial positions. Shareholders can then freely allocate their total shares among open directorships.

The rules governing the removal of directors work in parallel. Unless a corporation has a staggered board and/or cumulative voting, "[a]ny director or the entire board may be removed, with or without cause, by the holders of a majority of the shares then entitled to vote." ${ }^{61}$ Directors can thus be removed by majority voting power unless a corporation has adopted a staggered board or cumulative voting. In the case of a staggered board, directors can only be removed for cause, ${ }^{62}$ and in the case of cumulative voting, directors can only be removed for cause, if a number of votes sufficient to elect that director oppose his or her removal. ${ }^{63}$ Lastly, if the holders of a particular class of stock are entitled to elect a director(s), a majority of that class of stock can (and is necessary to) remove a director so elected without cause. ${ }^{64}$ These parallel protections are necessary as soon as one recognizes the power of removal. If these limitations did not exist, a majority of voting power could always undo the point of a staggered

58. A corporation with a staggered board can elect a third of its directors each year for up to three years. DEL. CODE ANN. tit. 8, § 141(d) (2020).

59. Id. ("The certificate of incorporation may confer upon holders of any class or series of stock the right to elect 1 or more directors who shall serve for such term, and have such voting powers as shall be stated in the certificate of incorporation.").

60. Id. § 214.

61. Section $141(\mathrm{k})$ first establishes the rule that "[a]ny director or the entire board of directors may be removed, with or without cause, by the holders of a majority of the shares then entitled to vote at an election of directors," and then provides three qualifications. Id. § 141(k). There are exceptions in Section 141(k)(1)-(2) for a corporation with a staggered board or cumulative voting, and the provision ends by stating that if a specific director(s) is elected by a particular class or series of stock then a majority of the holders of that class or series can remove the director(s) without cause, rather than a majority of all outstanding shares. Id. §141(k)(1)-(2).

62. Id. $\S 141(\mathrm{k})$.

63. Under cumulative voting, a majority of voting power can remove a director if the entire board is being removed. Id. $\S 141(\mathrm{k})$.

64. Id. $\S 142$. 
board, cumulative voting, or class-specific voting rights by just voting to remove the director. ${ }^{65}$

Shareholders' right to approve certain fundamental transactions is simpler. Scattered through Delaware's corporate law are provisions requiring a shareholder vote on amendments to the corporate charter, mergers, the sale of all or substantially all assets, or the dissolution of the company ${ }^{66}$ The provisions require that the board propose each of these transactions and then, as a default, that a majority of outstanding shares vote to approve them.

\section{The Separation of Voting and Control}

This system affords great flexibility, but is nonetheless limited. It resolutely tethers the power to elect directors to voting power. As a result, implicit throughout much of the literature is the tendency to simply equate voting power with control.

Courts treat this statutory system as mandatory as to the charter and bylaws, as I will soon explain. The essential function of shareholder agreements lies in the fact that they are not so constrained. If shareholders choose to, they can use these agreements to allocate control rights directly by contract. This legal structure is implicit in much of the case law addressing private companies, but reaches its clearest articulation in Klaassen $v$. Allegro Development Corp. ${ }^{67}$

Eldon Klaassen was the founder, CEO, and seventy-percent shareholder of Allegro Development Corporation, a leading provider of energy trading software. Suffice it to say, under normal circumstances, he controlled the firm, as a controlling shareholder, director, and officer, wearing all three hats a corporate fiduciary can wear. As a result, it was something of a surprise for Klaassen when, after running the company for over twenty years, he showed up at a meeting of the board of directors one day and was promptly fired as CEO. Ordinarily, under corporate law's default rules, Klaassen could have simply removed the entire board and voted in a new slate of directors who would reappoint him as head of the firm. Not so with the board of Allegro, however, because Klaassen had contracted away those rights through a shareholder agreement that defined the composition of the board (presumably as a necessary part of the bargain for equity financing). ${ }^{68}$ The shareholder agreement granted the minority shareholders in Allegro the power to designate three of seven directors. It required that

65. See Emiliano M. Catan \& Marcel Kahan, The Never-Ending Quest for Shareholder Rights: Special Meetings and Written Consent, 99 B.U. L. REV. 743, 751-58 (2019).

66. See supra text accompanying note 55.

67. Klaassen v. Allegro Dev. Corp., No. CV 8626-VCL, 2013 WL 5739680, at *24 (Del. Ch. Oct. 11, 2013), aff'd, 82 A.3d 730 (Del. 2013), and aff'd, 106 A.3d 1035 (Del. 2014).

68. Id. at $* 9$. 
two of the directors would be "independent," which it defined as individuals Klaassen would suggest, but who could only serve if the minority shareholder approved of them. The common stock, essentially Klaassen, designated the last two directors. The shareholder agreement then required that all parties to the agreement-effectively all the voting power in the firm vote for those designees.

In the aftermath of his termination, Klaassen attempted to remove the directors who opposed him. The board contended that Klaassen was acting in violation of the shareholder agreement, which limited the power to remove a director to the shareholder who nominated him or her. Moreover, the bylaws were drafted so as to bind any shareholder of the firm, even nonparties to the shareholder agreement, to the voting system described above. The dispute thus provided an occasion for clarifying how the rules of corporate elections can and cannot be changed.

In the opinion, Vice Chancellor Laster stated that the corporation's bylaws arguably "attempt to authorize removal only for cause and to limit removal without cause," and that if the bylaws were interpreted to do so they would be invalid because the bylaws may not alter the basic statutory voting system. ${ }^{69}$ More broadly, the court noted that a charter or bylaw provision purporting to limit removal powers in a manner not contemplated by the DGCL would conflict with it and be unenforceable..$^{70}$ On the other hand, the court expressly endorsed the ability of the parties, acting through their shareholder agreement, to opt out of even these rules and thus alter Klaassen's voting powers and eliminate his removal powers. ${ }^{71}$ The court ruled that Klaassen had renounced his ability to "unilaterally fill" positions and "bound himself to support only nominees" designated under the agreement. ${ }^{72}$ Other cases have similarly noted that the statutory voting system is mandatory as to the charter and bylaws, but not to a shareholder agreement. ${ }^{73}$

69. Id. at *24; see also In re VAALCO Energy, Inc., S'holder Litig., Consol. C.A. No. 11775-VCL (Del. Ch. Dec. 21, 2015) (transcript) (holding that charter and bylaws provisions "provid[ing] for only for-cause removal in the context of a nonclassified board, conflict with Section 141(k) of the Delaware General Corporation Law and are, therefore, invalid").

70. Id.

71. Id. at 25 .

72. Id. at 27 .

73. Rohe v. Reliance Training Network, Inc., No. CIV. A. 17992, 2000 WL 1038190, at *16 n.49 (Del. Ch. July 21, 2000); id. at *11 ("[T] he stockholders' right to remove directors could not be impaired by either the certificate or the bylaws. ... Section $141(\mathrm{k})$ provides no limitation on the right of stockholders to remove a member of a non-classified board."). The Delaware Supreme Court's decision in Salamone v. Gorman, 106 A.3d 354, 370 (Del. 2014), explicitly acknowledges that a corporation could opt out of otherwise mandatory corporate law rules through a shareholder agreement. In Salamone, the court approvingly enforced a majority per capita (that is, per shareholder) as opposed to majority of voting power voting arrangement for directors. 
Frechter v. Zier illustrates the limits placed on experimentation outside of shareholder agreements. ${ }^{74}$ In Zier, a corporation had a bylaw that required "a super-majority vote of at least two-thirds of the voting power ... to remove directors." 75 The Delaware Chancery Court held that the bylaw ran afoul of the Delaware statutory provision, Section 141(k), which provides that "[a]ny director or the entire board of directors may be removed, with or without cause, by the holders of a majority of the shares."76 The court approvingly quoted Vice Chancellor Laster's decision in $V A A L C O$ as well, which found that Section 141(k) prohibited bylaws requiring cause for shareholders to remove directors. ${ }^{77}$ Then Vice-Chancellor, later Chief Justice Strine was explicit in the Rohe case, where he noted in dicta that " $[S]$ tockholders can bind themselves contractually in a stockholders agreement in a manner that cannot be permissibly accomplished through a certificate of incorporation." ${ }^{78}$ Section $141(\mathrm{k})$ may be the mandatory rule for the charter and bylaws, but it is not for contract, where Delaware's courts afford shareholders greater freedom. This is a foundational difference in how the law treats the charter and bylaws, on one hand, as opposed to the shareholder agreement, on the other: it will permit shareholders to opt out of the basic voting rules by contract, separating voting and control. ${ }^{79}$

\section{Contract and Consent}

Why? Far from being a doctrinal nicety, the courts' logic is actually deeply revealing about the architecture of corporate law. Delaware's courts (and some scholars of corporate law) are fond of characterizing the

74. C.A. No. 12038-VCG, 2017 WL 345142 (Del. Ch. Jan. 24, 2017).

75. Id. at $* 2$.

76. Id. at $* 8$. The court noted that this provision includes two exceptions, discussed in the text here, and not relevant to the case.

77. Id. (" $141(\mathrm{k})$ states affirmatively 'any director or the entire board of directors may be removed, with or without cause, by the holders of a majority of the shares then entitled to vote at an election of directors.' That is the rule." (citation omitted)).

78. Rohe, $2000 \mathrm{WL} 1038190$, at *11 (emphasis added); id. ("As a result [of mandatory annual elections], RTN must hold an annual meeting for the election of directors, regardless of whether Article VIII of its Certificate of Incorporation was originally intended to provide a permanent tenure for the seven identified directors.").

79. Klaassen also illustrates that a court will provide a remedy of specific performance if a party violates a shareholder agreement. In Klaassen, the court held that actions that would otherwise be valid - the removal of directors by majority voting power-have no effect, rather than awarding monetary damages. Shareholder agreements routinely request specific performance, and courts have granted it in multiple cases. See, e.g., Blaustein v. Lord Baltimore Capital Corp., No. CIV.A. 6685-VCN, 2012 WL 2126111, at*7 (Del. Ch. May 31, 2012) (suggesting the specific performance remedy is appropriate for a violation of a shareholder agreement); TR Inv'rs, LLC v. Genger, No. CIV.A. 3994-VCS, 2010 WL 2901704, at *22 (Del. Ch. July 23, 2010), aff'd, 26 A.3d 180 (Del. 2011); Gildor v. Optical Sols., Inc., No. 1416-N, 2006 WL 4782348, at*11 (Del. Ch. June 5,2006 ) (Strine, V.C.) (ordering specific performance of preemptive rights granted by shareholder agreement where agreement seeks such remedy). 
corporate charter and bylaws as a contract between the corporation and its shareholders. ${ }^{80}$ It seems to flow naturally from the famous conception of the corporation as a "nexus of contracts" amongst the various patrons of the firm. Indeed, in the recent case, ATP Tour, Inc. v. Deutscher Tennis Bund, the Delaware Supreme Court went so far as to state that the "corporate bylaws are 'contracts among a corporation's shareholders." "81 The Chancery Court echoed the sentiment, declaring that "the bylaws of a Delaware corporation constitute part of a binding broader contract among the directors, officers, and stockholders." 82 The metaphor has its attractions because the charter and bylaws are legal devices individuals use to facilitate their voluntary relationships. But the metaphor can also be misleading. Under corporate law, the terms of a charter can be altered if the board votes for a change and a majority of shares vote likewise. The charter can be altered nonconsensually, in other words; if it is a contract, it is a sui generis one. Similarly, the bylaws can usually be unilaterally altered by the board of directors and subordinate the rights of a shareholder without her consent. This is not true of an ordinary contract that can, by default, only be amended with the consent of all parties.

Indeed, when pressed, Delaware's courts have taken seriously the idea that there are different varieties of voluntariness worth wanting. Klaassen contrasts the charter and bylaws with the "contractual overlay" added by a shareholder agreement that can further constrain the rights parties possess. ${ }^{83}$ As a result, a different paradigm of scrutiny is applied to the charter and bylaws versus the shareholder agreement. While the DGCL sets out the limits of the charter's freedom to alter voting, the limits of freedom in a shareholder agreement are wider-the generic limits of freedom of contract, public policy. ${ }^{84}$

80. See, e.g., Frank H. Easterbrook \& Daniel R. Fischel, The Corporate Contract, 89 COLUM. L. REV. 1416, 1433 (1989).

81. 91 A.3d 554, 557 (Del. 2014) (quoting Airgas, Inc. v. Air Prods. \& Chems., Inc., 8 A.3d 1182, 1188 (Del. 2010)). 2013).

82. Boilermakers Local 154 Ret. Fund v. Chevron Corp., 73 A.3d 934, 939 (Del. Ch.

83. Klaassen v. Allegro Dev. Corp., No. CV 8626-VCL, 2013 WL 5739680, at *24 (Del. Ch. Oct. 11, 2013), (treating the charter and bylaws as subject to the DGCL's mandatory rules, but not a shareholder agreement); see also id. at *22 ("[T]he Charter and Bylaws allocate various rights to the different classes of stockholders, then the Stockholders' Agreement adds a contractual overlay that constrains the manner in which the parties to that agreement can exercise their rights.").

84. So, in Salamone v. Gorman, 106 A.3d 354, 370 (Del. 2014), the Delaware Supreme Court could say of a shareholder agreement, "When parties have ordered their affairs voluntarily through a binding contract, Delaware law is strongly inclined to respect their agreement, and will only interfere upon a strong showing that dishonoring the contract is required to vindicate a public policy interest even stronger than freedom of contract." Id. 


\section{E. A Case Study in Separating Voting and Control: Control Sharing}

Parties value the ability to contract over their votes and other control rights. While there are many reasons for this, I will explore empirically one reason that parties value the ability to contract over their votes: it facilitates shareholders' ability to share control in ways that would otherwise be difficult to achieve.

Here, I discuss what control sharing is, before turning to how shareholder agreements distinctively facilitate control sharing arrangements. A very stylized vision of corporate power relies on two poles to characterize ownership and governance. At one end stands the widely dispersed shareholding structure considered the norm for public corporations in the Anglo-American world. The "separation of ownership and control" noted by Berle and Means relies on this conception, and it has often defined the focus of scholarship on U.S. corporations. At the other end is the corporation with a controlling shareholder, whether a single individual, institution, or family. This is often considered the norm for the rest of the world. Yet, a vast range of alternatives lie between these two poles. An important set of arrangements are those in which control is shared, and evidence suggests that it is the norm in startups and venture capital-backed private corporations. ${ }^{85}$ Understanding how these arrangements work has been a central focus of the venture capital literature. ${ }^{86}$ A control sharing arrangement can be thought of as any ownership structure in which multiple shareholders play a role in controlling firm affairs,. I will focus on control sharing where two or more distinct shareholders have designees on the board of directors and are influential in the management of the corporation. ${ }^{87}$

85. See, e.g., Michael Ewens, Ramana Nanda \& Matthew Rhodes-Kropf, Cost of Experimentation and the Evolution of Venture Capital, 128 J. FIN . ECON. 422 (2018).

86. In a seminal paper, Kaplan and Strömberg find that in the majority of venture capitalbacked firms, no single shareholder or set of aligned shareholders (say the founder or the venture capitalists) dominate the board. Instead, control is shared. Kaplan \& Strömberg, supra note 16, at 288. Indeed, control sharing is a central theme of the literature on venture-backed firms, which emphasizes the conflicts amongst those sharing control. See, e.g., Brian Broughman \& Jesse M. Fried, Carrots and Sticks: How VCs Induce Entrepreneurial Teams to Sell Startups, 98 CORNELL L. REV. 1319, 1329 (2013); Elizabeth Pollman, Startup Governance, 168 U. PA. L. REV. 155, 221 (2019); see also Jill E. Fisch \& Simone M. Sepe, Shareholder Collaboration, 98 TEX. L. REV. 863 (2020) (discussing the two models of the firm that dominate corporate law).

87. To be clear, not every corporation with more than one shareholder holding more than five percent or ten percent of stock is a firm subject to control sharing. The largest shareholders of many U.S. public corporations are now large mutual fund families, such as BlackRock, Vanguard, and State Street. See, e.g., Martin C. Schmalz, Common-Ownership Concentration and Corporate Conduct, 10 ANN. REV. FIN. ECON. 413, 415 (2018). They do not participate in a control-sharing arrangement, however, as I define it, because they do not secure directorships on the board of any of those firms. To my knowledge, none of the major shareholders in any of those firms has a board designee. (The reasons that large fund families do not seek directorships are many and subtle, including restrictions under the Investment Company Act and the loss of lighter treatment under Section 13 and Section 16 of the Securities Exchange Act. See John D. Morley, Too Big to Be Activist, 92 S. CAL. L. REV. 1407 (2019).) Thus, the fact that large shareholding is 
Shareholder agreements facilitate control sharing in at least two distinct ways. One occurs when shareholders are granted direct power over firm transactional decisions, such as when shareholders are granted veto rights over a change of control or the firing of the CEO. In this sense, control is shared between shareholders and the board.

The other occurs through voting agreements, whereby shareholders share control among themselves by allowing noncontrolling shareholders to credibly and flexibly secure directorships over a multi-year period. In particular, they insulate minority shareholders' board designees from the statutory right of a majority of voting power to remove that director. Otherwise, it is difficult for a minority shareholder to secure a directorship under the statutory rules for elections and removal. Under the default rules, in a firm with a controlling shareholder that shareholder can elect the corporation's entire board. The controlling shareholder can informally promise to elect the nominee(s) of a minority shareholder, but the minority shareholder will face all the concerns that make contract a generically attractive way to manage commitments. In a firm without a controlling shareholder it remains extremely hard for a minority investor to assure itself that it will be able to secure the election of its directorial nominee because each year the shareholder must informally cobble together a coalition of supporters with sufficient voting power to elect its candidate. Shareholder agreements, on the other hand, empower shareholders who alone or in coalitions possess controlling voting power to directly and credibly assure a minority shareholder that its directorial nominee will be appointed and provide great flexibility in doing so.

To illustrate, consider the following provision, which, in some variant, is common in my sample of shareholder agreements. It returns us to GoDaddy. GoDaddy's shareholder agreement includes governance provisions involving three blockholders, KKR, Silver Lake, and founder Bob Parsons. Following the IPO, each party owned $23 \%$ of the corporation's stock. Their shareholder agreement provides that so long as KKR or Silver Lake owns $10 \%$ of the company's common stock, KKR and Silver Lake will each be entitled to nominate two directors (and if they own at least $5 \%$, one director), and that as long as Parsons owns 5\%, he will have the right to nominate one director, and that all three parties will vote for one another's board nominees. Moreover, none of the three shareholders can sell their shares without the permission of both KKR and Silver Lake. By entering into an appropriate shareholder agreement, these three shareholders credibly committed themselves to securing board positions for years into the future. They contracted to vote for each other's board nominees and not to sell their shares, all of which is clearly enforceable under

ubiquitous in U.S. public firms should not be taken to suggest that control sharing is common as well. Clifford Holderness, The Myth of Diffuse Ownership in the United States, 22 REV. FIN. STUD. 1377 (2007). 
Delaware law. If the board has nine directors, the group can secure five directorships for as long as the coalition of minority shareholders maintain their ownership positions.

Some of what can be done by shareholder agreement cannot be done by corporate charter. For instance, a shareholder agreement can contractually determine ex ante the identity of the specific individuals (or specific shareholders' designees) who will compose the various committees of the board (e.g., compliance, nomination, governance), identify who will serve as the chairperson of the board of directors, or specify that a specific office holder (e.g., the CEO) will be a director of the board ${ }^{88}$ Further afield from control rights, shareholders can also waive by contract other statutory rights that the charter and bylaws cannot abrogate. ${ }^{89}$

But shareholder agreements are not the only way to displace the default rules and create some form of control sharing. There are a range of inflexible tools and one other powerful and flexible device for facilitating control sharing, although it is only a partial substitute for a shareholder agreement. An example of an inflexible alternative is cumulative voting. While it can provide minority investors with guaranteed board representation, cumulative voting fails to provide anything like the flexibility of the voting arrangements in shareholder agreements. There is, however, a robust and flexible alternative that can achieve many of the same ambitions: namely, class-specific voting rights, and more specifically, class-specific directorships. That deserves its own discussion, which I turn to next.

\section{F. Charters, Contracts, and Control Sharing}

Determining the composition of the board ex ante, however, can be done with relative flexibility by using either a shareholder agreement or the corporate charter with class-specific voting rights. Delaware law allows corporations to issue multiple classes of stock, and to grant separate classes different voting powers, preferences, or other special rights. ${ }^{90}$ A corporate charter can thus confer upon the holders of a specific class or series of stock the right to elect one or more specific directors. ${ }^{91}$ This is obviously an important partial substitute for a shareholder agreement's voting provisions. By causing the corporation to issue a new class of stock with rights to elect a specific director(s), a majority shareholder can credibly assure a minority

88. The reason why a charter could not implement any of these governance arrangements returns to Klaassen and Vaalco, discussed above. Namely, the charter may not abrogate shareholders' power to remove directors without cause.

89. See infra Section V.A.2.

90. Section 151(a) authorizes corporations to issue multiple classes of stock with voting power, preferences, or other special rights that differ among the classes. DEL. CODE ANN. tit. $8, \S$ 151(a) (2020).

91. Section 141(d) provides that the charter may confer upon the holders of a specific class or series of stock the right to elect one or more specific director positions, and to define the voting powers of that director. Id. §141(d). 
investor a long-term board position. Indeed, class-specific directorships illustrate a more general feature of shareholder agreements, which is that contract and capital structure emerge as partial substitutes for one another. A shareholder who wants to secure a directorship can do so either by acquiring the requisite amount of stock that confers that voting power or by obtaining contractual commitments from other shareholders.

Here, I compare the two legal technologies from the perspective of private parties crafting governance. In Part VI, I will consider shareholder agreements from a welfare perspective. The most important difference between securing directorships through the charter versus a voting agreement returns us to the procedural differences between the two instruments. It is the necessary involvement of the board in amending the charter. The creation of classes of stock requires corporate action, while a voting agreement need not involve the board at all. This can be important even when the corporation is a signatory to the shareholder agreement because the corporation enters other commitments. It remains importantly true that the board's approval is not required for the voting agreement.

The involvement of the board has several noteworthy implications. First, it means that a board's decision to create class voting is a decision subject to fiduciary scrutiny. Such a decision can be challenged as a violation of the duty of loyalty. ${ }^{92}$ Second, it means that shareholders who are opposed by the board cannot secure directorships through the creation of charter classes. Consider the case of four fifteen-percent minority shareholders seeking to form a controlling coalition. As yet, they have no control of the board and it could be difficult or impossible for them to convince the current board of directors to create multiple classes of stock to suit their interests. It is in their power immediately, however, to enter a shareholder agreement with one another, without having to bargain with the incumbent board. More generally, the board owes fiduciary duties, while each of several distinct minority shareholders owe no fiduciary duties, unless they are found to be a control group.$^{93}$ From the perspective of shareholders who can and do bargain directly with one another, the involvement of the board, with its own legally required fidelities, may be viewed as a significant bargaining friction they would rather avoid.

In addition, class-voting rights and voting agreements can make revisiting a firm's governance structure difficult, although in different ways. Because most voting agreements do not alter the contractual default of unanimity for any amendment, they cannot be altered without all signatories' consent. At least in principle, however, parties could choose a different

92. For recent fiduciary litigation involving the creation of classes of stock, see, for example, Consolidated Verified Class Action Complaint, In re Facebook, Inc. Class C Reclassification Litig., C.A. No. 12286-VCL (Del. Ch. June 6, 2016); and Verified Class Action Complaint at 7, In re Google Inc. Class C S'holder Litig., C.A. No. 7469-CS (Del. Ch. Apr. 2012).

93. See infra Section V.B.1. 
voting rule for subsequent amendments. For the charter, Delaware law provides for certain mandatory class-specific voting rights. Under Section 242(b)(2), if an amendment to the charter would "alter or change the powers, preferences, or special rights of the shares of such class so as to affect them adversely," then the shareholders of that class of stock must separately vote to approve a charter amendment for it to be adopted. ${ }^{94}$ As a result, every new class of stock added means that there is an extra set of persons who are sometimes entitled to a mandatory separate vote on changes to the charter. Here, too, parties can (and do) alter the default rule for amending the charter to make subsequent changes to class voting provisions subject to the approval of the holders of that class of stock.

The generic features of both instruments will also sometimes tip the balance. It will be easier and cheaper (especially in a public company) to renegotiate a contract than to go through the involved process of amending the corporate charter. Especially in a public firm, revising a shareholder agreement among a subset of shareholders will also have a far lower profile than revising the corporate charter. Charter amendments in public firms are costly affairs that require discussion in corporate proxy statements and public votes at corporate meetings.

Lastly, in private companies (and perhaps in public ones) there are additional differences. For instance, a private company need not publicly disclose a shareholder agreement but must file its charter with the Secretary of State. Firms with a secrecy interest in their governance may thus prefer a shareholder agreement.

The combined effect of all of these costs is to drive a meaningful wedge between the two legal technologies. They can both secure directorships for minority shareholders and thus facilitate the sharing of control, but the similarities end there. Differences in the duties owed, the necessary involvement of the board, and the downstream consequences for firm complexity mean the two are, in material respects, distinct.

\section{Empirical Analysis}

This Part presents the universe of shareholder agreements in firms that have gone public over the last six years. I first describe how the dataset was assembled. I then analyze the terms of the agreements and discuss characteristics of the firms subject to them. I then test a hypothesis based on the case study of the value of control sharing discussed above.

94. DeL. CoDE ANN. tit. 8, § 242(b)(2) (2020); see also Hartford Accident \& Indemnity \& Co. v. W.S. Dickey Clay Mfg. Co., 24 A.2d 315 (Del. 1942) (narrowly construing the reach of the 242(b)(2) class vote); McDonnell, supra note 25, at 417 ("In Delaware, a certificate amendment that affects the rights of an existing class of shareholders must be subject to a class vote, whether or not the existing certificate provides for that."). Delaware courts have narrowly interpreted the meaning of adverse effects on a class's "powers, preferences, or special rights." See, e.g., Benchmark Capital Partners IV, L.P. v. Juniper Fin. Corp., 822 A.2d 396 (Del. 2003). 


\section{A. Data}

To understand the function of shareholder agreements, I assemble an original dataset of them. To collect data, I go through every company (901) that went public from 2013 to 2018 (inclusive), based on a widely-used source on IPOs..$^{95}$ I manually identify whether the company disclosed a shareholder agreement in connection with its IPO. ${ }^{96}$ Because identifying and analyzing the agreements is intensive, I choose six years for tractability and to focus on the newest public companies.

The majority of companies conducting an IPO disclose that they either have been or are a party to a shareholder agreement (55\%). About $40 \%$ of IPO firms disclose that they were a party to a shareholder agreement, but that all of its terms, other than registration rights, terminate as of the IPO. However, $15 \%(N=139)$ of companies conducting an IPO disclose that they are going public subject to a shareholder agreement. The agreement may be one already in place, or, more usually, a revision of a prior agreement or a new one. In all cases, however, the parties to the agreement are already shareholders of the corporation going public, i.e., pre-IPO shareholders.

I focus on and code this set of post-IPO shareholder agreements. They vary in length from ten pages to over one hundred, but they are generally about thirty pages long. Based on the background scholarly and practitioner literature and the preliminary review of a small number of agreements, I design a coding rubric that consists of thirty-six variables. ${ }^{97}$ The coding system begins by noting the agreement's name, the parties, identity of the main parties (entities or natural persons), and whether the corporation itself is a party to the agreement. The rubric focuses on control rights, but also covers a number of other issues, including the existence and nature of any transfer restrictions, whether parties to the agreement are selectively granted access to firm information, and whether there is a waiver of the corporate opportunity doctrine.

As noted earlier, understanding how shareholder agreements alter shareholders' control rights benefits from distinguishing between their "horizontal" and "vertical" dimensions. An example of a "pure" horizontal agreement would be a voting agreement among shareholders to which

95. I use the IPO Scoop IPO list suggested by Jay Ritter with 901 U.S.-domiciled IPOs. Scoop Track Record from 2000 to Present, IPO SCOOP, https://www.iposcoop.com/scoop-trackrecord-from-2000-to-present [https://perma.cc/MLZ2-WPVF].

A focus on U.S. domiciled operating companies is the norm in the IPO literature. If one includes foreign domiciled companies, real estate investment trusts, and limited partnerships, however, the percentages do not materially change.

96. If a company will be a party to a shareholder agreement after its IPO, it should disclose the agreement because it is material to its governance. As a result, the agreement should be publicly filed on the Securities and Exchange Commission's Electronic Data Gathering, Analysis, and Retrieval system. 0 website, which provides access to more than 21 million filings.

97. The coding system is available upon request. 
the corporation is not a party. A "pure" vertical agreement could involve the corporation granting veto rights to a specific shareholder and committing to support its board nominees.

Most of the coding system is dedicated to the contractual assignment of control rights, which involves both horizontal and vertical elements. It begins by analyzing how agreements contract over the composition of the board of directors. The first few variables here address how agreements create nomination rights to the board of directors and effectuate those rights. I code (i) whether agreements grant shareholders' rights to nominate directors, and if so, who possesses those rights and what the thresholds are for exercising them (e.g., KKR can nominate three directors as long as it owns $20 \%$ of company stock and two directors if it owns between $10 \%$ and $20 \%$ ); (ii) whether the company commits to support a shareholder's board designees, including whether it will place the designee in the company's slate of nominees and whether the company must take efforts to elect the nominees (e.g., the corporation commits to include KKR's nominees in its proxy slate and make its best efforts to ensure their election); and (iii) whether there is a "fiduciary out" if the board believes the nominee is unfit (e.g., the corporation can reject a designee that the governance and nominating committee considers not in the company's best interests and contrary to its fiduciary duties). I also code for whether there is an agreement among shareholders to vote for specific nominees, including who the parties are and the obligations created by the voting agreement (e.g., all signatories commit to vote for KKR's nominees).

The other major dimension of control rights are veto rights granted to specific shareholder(s). I code for whether an agreement grants veto rights, who holds them, and what the minimum ownership threshold is for the retention of those rights. I also code for thirteen specific veto rights as well as a catch-all category for other vetoes.

\section{B. Shareholder Agreements in Practice}

The agreements show shareholders contracting over all of the classic default rights of exit, voice, and liability. Their core concern, however, is with bargaining directly over control.

Control: The Board. As Table 1 shows, most of the agreements alter the default system for electing the board of directors. The vast majority of the agreements confer on one or more shareholders the right to nominate one or more directors to the board. Those nomination rights are typically accompanied by horizontal and/or vertical commitments to the shareholder(s) board designee(s).

A majority of agreements include a voting agreement among the signatories in which shareholders commit to vote for specific board nominees. These voting arrangements vary widely. Two large minority shareholders 
may both possess rights to nominate up to a third of the board, depending on their ownership percentages, and contract to vote for each other's nominees (a symmetric voting arrangement). Other times, a large number of shareholders will contract to vote for a specific shareholder's nominees (an asymmetric voting arrangement). If the parties to the voting agreement hold over fifty percent of voting power, then they guarantee the nominees' election. Even if the parties' shares aggregate to less than majority voting power, aggregated shares will often be sufficient to ensure nominees' election in practice.

In a majority of agreements, the corporation itself contracts to support the individuals that shareholders designate based on their contractual rights. Usually this means that the corporation commits (1) to include the designee in the slate of candidates that the corporation recommends shareholders elect, and (2) to make its best or reasonable efforts to ensure the designees' election. For example, Sabre Corporation commits to "take all Necessary Action to cause the Board of Directors and Governance and Nominating Committee to ... include [shareholder] Designee[s] in the slate of nominees recommended by the Board of Directors . . . for election by the stockholders of the Company" and to "solicit proxies or consents in favor thereof." 98

Control: Veto Rights. A significant minority of agreements grant veto rights (or equivalently, approval rights) to one or more shareholders over specific corporate decisions $(50,36 \%)$. Table 2 depicts the percentage of times a given veto right exists when the firm grants at least one veto right. The typical threshold for when these veto rights cease to exist is when a party's ownership stake falls below a given percentage, which is usually between $30 \%$ and $50 \%$. Common subjects of vetoes are changes of control, hiring or firing the CEO, or material new issuances of equity.

Corporate Opportunity Waivers. The officers, directors, and controlling shareholder(s) of a corporation owe the corporation fiduciary duties of care and loyalty. Loyalty, the core duty and the source of virtually all enforcement of fiduciary duties, is generally treated as a mandatory rule by Delaware corporate law. ${ }^{99}$ The sole exception is that a component of the duty of loyalty, known as the corporate opportunity doctrine, is waivable by a corporation. ${ }^{100}$ The corporate opportunity doctrine generally requires fiduciaries who encounter a new business opportunity that lies in the corporation's line of business to present it to the corporation before pursuing it themselves. Failure to do so can violate the duty of loyalty.

98. Sabre Corp., Amended and Restated Stockholders' Agreement, S-1, Ex. 10-45, at 11.

99. This means that even if every party in control of the corporation, including its officers, directors, and shareholders, consent to waive the duty of loyalty, that waiver is not enforceable.

100. Del. Code AnN. tit. $8, \S 122(17)$ (2020). See generally Rauterberg \& Talley, supra note 51 (explaining Delaware's adoption of a statutory provision empowering corporations to renounce corporate opportunities otherwise belonging to them under the duty of loyalty). 
Waivers can be placed in a corporation's charter or any other instrument approved by the board. They enable a fiduciary to pursue a business opportunity without fear of violating the duty of loyalty. Fifteen percent of agreements adopt a corporate opportunity waiver.

Transfer Restrictions. Under the default rules of Delaware law, shares are freely transferable by any holder, but it is well known that private companies extensively restrict the transferability of shares. In a minority of shareholder agreements, one of a number of transfer restrictions are established. They vary enormously in character and prove to be incredibly complex. For these reasons, I defer analysis of them for future work.

Other Provisions. The agreements contain a wealth of other provisions. Many are generic features of contracts that nonetheless reflect concerns distinctive to shareholder agreements. For instance, this can be as simple as termination provisions that routinely take the form of ending the contract's obligations when a party's ownership stake falls below the lowest threshold for retaining a designation right. The agreements usually also contain a remedies provision stating that monetary damages would be insufficient and that specific performance is the appropriate remedy.

There are also provisions that are often included but were not coded. Two are especially worth noting. First, the corporation often commits to include shareholders' board nominees on specific committees, such as audit, governance, and executive committees, or on all committees. Second, most if not all voting agreements are accompanied by removal provisions restricting the ability of the agreement's signatories to remove a board member unless the shareholder who designated that board member consents.

\section{Characteristics of Adopting Firms}

Shareholder agreements are principally governed by state corporate law, and thus the state of incorporation of subject firms is of interest. ${ }^{101}$ Table 3 presents a comparison of the states of incorporation of U.S.-headquartered new public firms (that conducted an IPO between 2014-2018), breaking them down between those that were subject to a shareholder agreement when public and those that were not. Delaware's share of incorporations is ninety-one percent among adopters and eighty-four percent among nonadopters of agreements.

Relative over-representation of adopters in Delaware has at least two plausible explanations. First, the parties to shareholder agreements, as we will see, tend to be a set of sophisticated financial actors, and firms with

101. I match firms subject to shareholder agreements with the Compustat and S\&P Capital IQ databases, which enables me to link these firms with an array of background legal and financial information. While matching firms increases the richness of potential analysis, it also results, as is often the case, in some data loss. 
more sophisticated investors may be more likely to incorporate in Delaware. Second, the Model Business Corporation Act's (MBCA) legal provisions empowering shareholder agreements are complex and have been subject to recent change. ${ }^{102}$ As a result, the status of shareholder agreements in public companies in MBCA jurisdictions is suspect.

Table 4 compares the industries to which adopters and nonadopters belong. There are several contrasts of note. Both firms with and without shareholder agreements are well represented in the broad "tech" field of computer programming. Firms subject to shareholder agreements are represented slightly more in oil and gas services, while firms without shareholder agreements are likelier to be in biological products.

Finally, I compare a number of financial metrics for firms that are subject to shareholder agreements and those that are not in Table 5. In principle, this comparison could provide suggestive evidence of harmful effects of shareholder agreements. If firms that adopt shareholder agreements are systematically smaller, with fewer assets, lower market value, and higher debt, then it might suggest an association between poor-quality firms and shareholder agreements. Table 5 illustrates that the opposite is the case.

102. Outside Delaware, the MBCA is the most prominent source of corporate law rules. Like Delaware statutory law, the MBCA expressly empowers shareholders to craft shareholder agreements. The central provision is section 7.32, and its language is mirrored in the statutory law of a large number of states. MODEL BUS. CORP. ACT § 7.32 (AM. BAR Ass'N 2017) (“Section 7.32(a) validates virtually all types of shareholder agreements that, in practice, normally concern shareholders and their advisors.”); see, e.g., MODEL BUS. CORP. ACT ANN. §§ 7-275-7-277 (AM. BAR ASS'N 2013) (compiling a list of over twenty states with identical or similar provisions to section 7.32). Section 7.32 of the MBCA upholds an "agreement among the shareholders of a corporation that complies" with the provision, even if the agreement is inconsistent with a wide variety of other MBCA rules. MODEL BUS. CORP. ACT $§ 7.32$ (AM. BAR Ass'N 2017). Under section 7.32, a shareholder agreement can be inconsistent with MBCA rules by: restricting the discretion of the board of directors $(\$ 7.32(\mathrm{a})(1))$; " establish[ing] who shall be directors or officers of the corporation, or their terms of office or manner of selection or removal" (\$ 7.32(a)(3)); and more. See id. § 7.32(a)(1)-(8). However, section 7.32 imposes a wealth of procedural requirements on shareholder agreements. For instance, a section 7.32 agreement must be approved by each person who is a shareholder at the time of the agreement and noted conspicuously on the certificates of outstanding shares. Id. $\S 7.32(\mathrm{~b})(1)$ (providing an information statement is an acceptable substitute for notice on a share certificate). Failure to obtain unanimous adoption means that the shareholder agreement fails to qualify for the special exemptions of section 7.32. Further, until quite recently, the MBCA specifically provided that a shareholder agreement authorized under section 7.32 ceased to be effective when the subject company became public, explicitly depriving public companies of the largesse of section 7.32. See, e.g., Committee on Corporate Laws, Changes in the Model Business Corporation Act - Proposed Amendments Relating to Chapter 1 and Chapter 8 (including Subchapters $F$ and $G$ and Duties of Directors and Officers), 59 BUS. LAW. 569, 632 (2004); id. § 7.32(d). The most recent version of the MBCA removed specific reference to public corporations. Even under the previous MBCA, though, a shareholder agreement that did not comply with $\S 7.32$ was not necessarily invalid. Rather, it was cast back to complying with the MBCA rules from which $\$ 7.32$ provided an exemption. See id. $\$ 7.32$ (Official Comment) ("Before the introduction of section 7.32 in 1990, the Model Act did not expressly validate shareholder agreements ...."). The implications for shareholder agreements in public companies governed by a version of the MBCA's rules are not crystal clear. One implication seems to be that a nonunanimous shareholder agreement in a public company cannot provide for any of the features from which sections 7.32(a)(1)-(8) provide an exemption. 
New public companies with a shareholder agreement have much higher total assets, market value, and cash, although also higher debt. I conduct simple difference of means tests that show different means at conventional significance levels.

Lastly, I informally explore the ownership histories of a subset of the firms subject to shareholder agreements. ${ }^{103}$ Private equity firms are by far the most common institutional signatory to the agreements, while other common institutional signatories are public and private companies, venture capital firms, and hedge funds. Natural persons are also common signatories to these agreements. While I do not explore this issue, it is probable that most of these parties unwind their ownership positions over time, limiting the duration of the shareholder agreements. The agreements typically provide that the rights and duties under them terminate when the signatories' ownership position falls below a defined threshold (such as five percent).

\section{Exploring Control Sharing Among Minority Investors}

I turn now to exploring the view that shareholder agreements facilitate control sharing by empowering investors to bargain over the composition of the board.

It is essential to recognize that control sharing is possible without shareholder agreements. Otherwise, the relationship would be tautologous. As noted earlier, cumulative voting permits a limited form of control sharing and class-specific directorships permit a far more flexible form. Control sharing could also exist exclusively on an informal basis as two shareholders could commit, without legal scaffolding, to vote their shares together. The focus here is to determine whether the control sharing arrangements we can observe generally depend on shareholder agreements or whether they are common without them. A direct test of the relationship between shareholder agreements and control sharing would compare two sets of firms that are identical, except for the fact that in one set control is shared among shareholders. It would then test for whether firms in the second set are subject to agreements among shareholders that contract over directorships.

The direct test is obviously unavailable. Shareholder agreements, like all contracts, are the product of shareholders' deliberate responses to their economic and legal environment. As a result of this endogeneity, the setting does not support causal inference. I explore whether the evidence is consistent with shareholder agreements facilitating horizontal control sharing.

\footnotetext{
103. I use S\&P Capital IQ for this exercise.
} 
The direct test described above faces another potentially fatal obstacle: control is difficult to observe. A shareholder who possesses fifty percent of voting power can be directly observed and is treated as a de jure controlling shareholder under corporate law. But the set of control arrangements in which control is shared necessarily involve either a shareholder with controlling voting power sharing control, or more predictably, individual minority shareholders sharing control. The Delaware courts are sometimes required to assess whether a group of minority shareholders are acting as a group that constitutes a controlling shareholder. They employ a "facts and circumstances" approach that benefits from a rich evidentiary record produced by litigants' discovery. They nonetheless find the task difficult, and the resulting conclusions are routinely criticized. ${ }^{104}$

I avoid this problem by exploiting a specific feature of stock exchange listing requirements. Under both New York Stock Exchange and NASDAQ listing standards, a company in which more than fifty percent of voting power is held by an individual, institution, or group constitutes a "controlled company." 105 A controlled company qualifies for exemptions from otherwise mandatory governance requirements for public companies, particularly the requirement that a majority of the board of directors consists of "independent directors." 106 In determining whether a group exists, the exchanges follow the definition of "group" under federal securities law, which is extremely broad. ${ }^{107}$

I use the "controlled company" definition to operationalize this hypothesis: Controlled companies in which a group of distinct minority

104. See Ann M. Lipton, After Corwin: Down the Controlling Shareholder Rabbit Hole, 72 VAND. L. REV. 1977 (2019).

105. See Corporate Governance Requirements, NASDAQ REG. §5615(a) (listing exemptions from certain corporate governance requirements); Listed Company Manual, N.Y. STOCK EXCHANGE $\quad \S \quad 303 \mathrm{~A}, \quad \mathrm{https} / /$ nyseguide.srorules.com/listed-company-manual/document?treeNodeId=csh-da-filter!WKUS-TAL-DOCS-PHC-\%7B0588BF4A-D3B5-4B91-94EABE9F17057DF0\%7D--WKUS_TAL_5667\%23teid-66 [https://perma.cc/3FXQ-D6QQ] (providing a similar definition and exemptions); NYSE Listed Company Manual Section 303A Corporate Governance Standards: Frequently Asked Questions, N.Y. STOCK EXCHANGE 7 (Jan. 4, 2010), https://www.nyse.com/publicdocs/nyse/regulation/nyse/final_faq_nyse_listed_company_manual_section_303a_updated_1_4_10.pdf [https://perma.cc/HB3E-8LXF] ("NYSE will look to the concept of 'group' set out in Section 13(d)(3) of the Exchange Act, and expects that generally a group would have an obligation to file on Schedule $13 \mathrm{D}$ or $13 \mathrm{G}$ with the SEC acknowle dging such group status, including disclosure that the group acts as such in voting for the election of directors."). Section 13(d)(3) of the Securities Exchange Act defines a group as existing "[w]hen two or more persons act as a ... group for the purpose of acquiring, holding, or disposing of securities of an issuer." 15 U.S.C. § 78m(d)(3) (2018); 17 C.F.R. § 240.13d-5(b)(1) (2020) (SEC regulations pursuant to provision providing analogous definition).

106. NYSE LISTED COMPANY MANUAL, Section 303A.00 (exempting controlled companies from complying with Sections 303A.01 [listed company boards must have a majority of independent directors], 303A.04 [listed companies must have a corporate governance committee of entirely independent directors] or 303A.05 [listed companies must have a compensation committee of independent directors]).

107. See supra text accompanying note 105 . 
shareholders hold over fifty percent of the voting power will be subject to a voting agreement among those shareholders. ${ }^{108}$

I hand collect information on the controlled company status and ownership of all firms in my sample for which I have confirmed Delaware incorporation. ${ }^{109}$ If a company (1) qualifies as a controlled company (2) due to the aggregation of multiple minority shareholders' voting shares, I classify it as a "control sharing firm" (or, equivalently, "minority controlled firm") because the minority shareholders necessarily are acting as a group exercising control (or the company would not qualify as controlled). For instance, as part of its IPO process, Shake Shack disclosed that it is a controlled company, intends to make use of the applicable exemptions, and that control results from the combined voting power of a group of investors, including both its founder, celebrity chef Danny Meyer, and a number of financial institutions. ${ }^{110}$ Recall that control sharing does not depend on the existence of a shareholder agreement among the investors. Any set of shareholders qualifying as a $13 \mathrm{D}$ or $13 \mathrm{G}$ group and holding voting power in excess of fifty percent would qualify as a controlled firm under exchange listing rules, and as a control sharing firm for me. Nonetheless, if a voting agreement does exist among shareholders holding sufficient voting power, then they will qualify as a control sharing firm. The hypothesis above is thus really about the importance of shareholder agreements in facilitating otherwise fragile control sharing arrangements. At most, it offers suggestive evidence that the null hypothesis - that control sharing among minority shareholders is easily facilitated without a shareholder agreement-is false.

The approach I use comes with a number of other caveats. First, the test I construct is a fairly weak one because it only allows us to observe a subset of control sharing firms, potentially only a small fraction. A firm in which control is shared but there is a single shareholder with over $50 \%$ of voting power may not identify itself as subject to a control group in its filings. More importantly, firms in which there is a control sharing arrangement among minority shareholders but their combined voting power falls below $50 \%$ will not qualify as a controlled company under listing

108. It is clear that no explicit agreement is necessary to qualify as a control group. See KN Energy, Inc. v. Gulf Interstate Co., 607 F. Supp. 756, 765 (D. Colo. 1983) (“[A]n agreement to act in concert need not be in writing or in any other way formalized ...."); van der Fluit v. Yates, No. CV 12553-VCMR, 2017 WL 5953514, at*5 (Del. Ch. Nov. 30, 2017) (“"The law does not require a formal written agreement."'). So, the hypothesis is really about the importance of shareholder agreements in facilitating otherwise fragile control-sharing arrangements and disproving the null hypothesis that control sharing among minority shareholders is possible without a shareholder agreement. for Reg. S-K.

109. Companies are required to disclose if they are controlled pursuant to instructions

110. Shake Shack Inc., Stockholders' Agreement (Jan. 20, 2015). 
requirements and thus will not be observed. ${ }^{111}$ Nonetheless, a firm with four $10 \%$ shareholders who coordinate voting could qualify as a controlling shareholder under Delaware law. ${ }^{112}$

Second, this empirical test-like all the empirical analysis presented here - is conditioned on a company having chosen to go public, which is a decision under its control. Thus, the analysis may not extend fully to private firms. Lastly, per Section IV.C, there are clearly other functions served by shareholder agreements. In particular, many firms subject to shareholder agreements use them to create fundamentally vertical obligations in which the substantive governance commitments are between the corporation and a shareholder. The existence and incidence of these are somewhat surprising. They are economically, normatively, and legally distinct, as will be discussed further below.

Table 6 presents basic summary statistics in which the unit of observation is the firm. There are 648 firms in the Delaware sample. Of all Delaware firms that go public between 2013 and 2018, 25\% are controlled companies under stock exchange definitions. An absolute majority of those firms are subject to a shareholder agreement. A strong majority of all firms with a shareholder agreement are controlled (79\%); only $22 \%$ of firms without a shareholder agreement are controlled. Twenty-one percent of firms with shareholder agreements are firms controlled by a group of minority shareholders, but only $4 \%$ of firms without a shareholder agreement are so controlled. Nonetheless, those $4 \%$ are a nontrivial number in absolute terms. They pose interesting questions as to what legal or nonlegal devices the minority shareholders in those firms are using to coordinate control. In fact, the relatively low incidence of controlled minority or control sharing status in firms with shareholder agreements may be more striking. Forty-five firms feature voting agreements. Almost by their nature, conceptually, these agreements create a control sharing arrangement. The fact that only twenty-eight show up under my test highlights again that it is under-inclusive. Table 7 cross-tabulates firms with and without control sharing arrangements based on whether they are party to a shareholder agreement or not.

The results are consistent with the view that shareholder agreements facilitate control sharing and that it is fragile in their absence. Firms subject to voting agreements are significantly more likely to be control sharing firms than firms without voting agreements.

111. One way to potentially remediate this in future research is to ascertain whether $13 \mathrm{G}$ filings disclose control-sharing arrangements, including those pursuant to and not pursuant to a voting agreement.

112. Delaware corporate law, the federal securities law, and stock exchange listing rules all employ distinct conceptions of control. Federal securities law has a capacious conception of a control group, Delaware law its conception of a controlling shareholder, and stock exchanges their bright-line rule of fifty percent. 


\section{The Welfare Effects of Shareholder Agreements}

What about the welfare effects of shareholder agreements? I try to sketch some of the major issues, but a few notes of caution are merited. First, little of empirical rigor is known about shareholder agreements in the United States, and for that reason alone it would be premature to offer a definitive view. Second, shareholder agreements are heterogeneous. They involve different devices and these devices raise distinct welfare questions. Indeed, different investors may well use the same provision for quite different purposes. Again, assessing these uses will turn on empirical issues that have not yet been studied. Finally, the question of how much freedom shareholders should possess in crafting corporate governance relates back to a classic debate about the place of mandatory rules in corporate law. Thirty years ago, in a symposium dedicated to the topic, a leading scholar asked: "To what extent should corporations be allowed to opt out of the rules of corporate law by adopting charter provisions to that effect? That is, should any corporate law rules be mandatory, and, if so, which rules? This is a fundamental question in the theory and life of corporate law." 113 Shareholder agreements raise that question in a new form-Should corporate law rules be mandatory, and if so, only as to the charter or as to contract too? - but the many complexities of that debate remain relevant. It is thus in a provisional spirit that I turn to a normative analysis of shareholder agreements.

I advance two related claims. First, the welfare case for horizontal agreements is stronger than the case for vertical commitments by a corporation. In essence, the availability of horizontal agreements increases the contracting space for Coasean bargains over control among shareholders. While I identify a tradeoff between the agency costs associated with the existence of control groups and the benefits of these bargains, it is unclear whether direct regulation can plausibly improve on parties' ability to evaluate those tradeoffs.

Second, the case for vertical shareholder agreements is more tenuous because they appear to be more of an "end-run" around the protections of

113. For the seminal symposium addressing this debate, see Lucian Arye Bebchuk, Foreword: The Debate on Contractual Freedom in Corporate Law, 89 ColuM. L. REV. 1395 (1989); and the articles of the symposium. A related and profound question beyond the scope of this paper is why corporate law offers investors less freedom than alternative entities, like the limited partnership and limited liability company, and why parties use shareholder agreements rather than adopting an alternative entity. For just some of the insightful work on alternative entities, see Peter Molk, How Do LLC Owners Contract Around Default Statutory Protections?, 42 J. CORP. L. 503 (2017); and Larry E. Ribstein, The Uncorporation and Corporate Indeterminacy, 2009 U. ILL. L. REV. 131; see also Fisch, supra note 33 (criticizing shareholder agreements for reasons that go beyond the effects on a firm's immediate shareholders as well, such as undermining the predictability and clarity of the corporate form). These are significant arguments I will address fully in subsequent work. 
charter amendments. Additionally, the extent to which some of these corporate commitments are arm's-length "bargains" at all is suspect, and some of them function as controlling minority structures that courts should subject to searching fiduciary scrutiny. ${ }^{114}$

\section{A. Horizontal Shareholder Agreements}

The basic argument for horizontal shareholder agreements is that by dint of the wider freedom granted them by courts, they increase the bargaining space for shareholders to tailor the structure of corporate control. For instance, significant investors can use shareholder agreements to secure directorships by facilitating bargains over the composition of the board, where they could otherwise do so only with greater friction (or not at all).

The fact that a significant number of pre-IPO investors make use of shareholder agreements suggests that they find the agreements consequential and valuable. And the usual welfarist logic in favor of contract seems plausible here as among the signatories to the agreement: if informed parties voluntarily enter into an agreement then we can presume it improves the lot of each (at least as measured by their own lights), and if there are no externalities for third parties, then the contract is Pareto improving. Given that the parties here are highly sophisticated, it is unlikely that the shareholder agreements they enter disserve their interests.

On the other hand, precisely because they facilitate the sharing of control, horizontal shareholder agreements may increase certain kinds of agency costs and reduce the welfare of nonsignatories. Agency costs in corporations can be usefully divided into two main categories: management agency costs that flow from the managers of a firm acting opportunistically toward shareholders, and control agency costs in which some shareholder(s), such as a controlling shareholder, act opportunistically towards the other investors. ${ }^{115}$ Because they facilitate control among shareholders, shareholder agreements should generally serve to reduce management agency costs because active shareholders are widely thought to be effective monitors of management.

On the other hand, these agreements may increase the agency costs to shareholders outside the control group if the control group acts opportunistically toward them. For instance, if the members of the control group are all private equity firms, then their interests may be aligned in certain

114. The literature on more familiar controlling minority structures, like dual class stock, is vast. For an important early example, see Lucian A. Bebchuk, Reinier H. Kraakman \& George G. Triantis, Stock Pyramids, Cross-Ownership, and Dual Class Equity: The Mechanisms and Agency Costs of Separating Control from Cash-Flow Rights, in CONCENTRATED CorPorate OWNERSHIP 295, 295 (Randall K. Morck ed., 2000).

115. Zohar Goshen \& Assaf Hamdani, Corporate Control and Idiosyncratic Vision, 125 YALE L.J. 560, 582 (2016). 
ways, such as favoring a sale of the firm, in a way that disserves other investors. The effect of shareholder agreements on these agency costs may in fact be lower than the alternative, however. If the alternative to a control group is a single controlling shareholder, then a control group may be attractive. This is because they own a large portion of the firm's cash flows, meaning they internalize much of the firm's success and have strong incentives to operate the company effectively, but because of their distinct interests, the control group may face collective action problems in extracting private benefits from the firm. ${ }^{116}$ From an agency cost perspective, the net effects of shareholder agreements are thus rather subtle. ${ }^{117}$

Does the empirical literature on IPO governance give us reason to lean strongly in one reason or the other? Probably not. In the early days of the economic analysis of law, the conventional wisdom was that firms went public with efficient governance because the IPO process subjected them to substantial scrutiny by prospective purchasers, analysts, and regulators. ${ }^{118}$ Because engaged market participants will pay less for a firm with poor governance, the argument ran, companies have strong incentives to put in place efficient governance to obtain a higher price for their shares. Thus, it concluded, we should take comfort in the efficiency of IPO governance. Decades later, it is surely true that investors generally price governance arrangements into their investment decisions to some extent.

However, a significant empirical literature calls into question whether IPO governance is optimal, and if you are less sanguine about the efficiency of the IPO process, then you may worry that these structures simply reward current controlling shareholder with outsized powers. ${ }^{119}$ From this perspective, a portion of the shareholder agreements I study could be seen as private company investors seeking to retain the powers of control and the governance technologies of private firm governance, while benefiting from public equity at the latter's expense. ${ }^{120}$

116. See Ronald J. Gilson, Henry Hansmann \& Mariana Pargendler, Regulatory Dualism as a Development Strategy: Corporate Reform in Brazil, the United States, and the European Union, 63 STAN. L. REV. 475, 498 (2011).

117. Beyond agency costs, there are other ways in which a horizontal agreement among shareholders could be opportunistically used as to a third shareholder. For an insightful exploration of this issue in the context of intercreditor agreements, see Kenneth Ayotte, Anthony J. Casey \& David A. Skeel, Jr., Bankruptcy on the Side, 112 Nw. U. L. REV. 255 (2017).

118. Michael Klausner, Fact and Fiction in Corporate Law and Governance, 65 STAN. L. REV. 1325, 1327 (2013) ("The contractarian logic is clearest at the point of a company's initial public offering (IPO).").

119. Id. at 1329 (arguing for evidence of dysfunctionality of the IPO process and claiming that "the empirical literature over the past three decades has provided little support for the contractarian theory").

120. Whether "midstream" agreements (i.e., those adopted once a company has been public for a while) should be more or less troubling remains an issue open to debate. See Choi et al., supra note 57 (exploring the midstream adoption of majority voting requirements). 
The Separation of Voting and Control

\section{B. Vertical Shareholder Agreements}

Shareholder agreements also involve commitments between corporations and shareholders. These commitments take several different forms, but the most common are the corporation (1) promising to support a specific shareholder's board nominees by including them in the corporation's proxy statement and/or using its best efforts to ensure their election, and (2) granting specific shareholder(s) veto rights over major issues of corporate policy. Other examples include granting shareholders and/or their designees corporate opportunity waivers and information rights. Many of these commitments may be, as I will argue later, unenforceable as a matter of corporate law.

There is a simple argument that these vertical agreements are efficient: they represent bargains struck between sophisticated corporations and investors that are presumptively in their joint interest. ${ }^{121}$ It is an argument that is plausible on its face, but it also gains fuel from the fact that corporations frequently enter into contracts involving veto or board nomination rights with their creditors.

Nonetheless, vertical shareholder agreements are troubling for reasons beyond those that also apply to horizontal agreements. The main reason is that they seem like a procedural end-run around the checks and shareholder involvement of a charter amendment. After all, shareholders can bargain over directorships by contract in ways they could not in the charter, but veto rights or corporate opportunity waivers could be placed in the charter (and commitments to support nominees indefinitely, wherever placed, may be unenforceable). Indeed, because the corporation is entering these contracts, the board is already involved. The fact that parties are choosing to accomplish by contract what they could do by charter amendment raises the concern that vertical shareholder agreements reflect an agency problem that would be checked by a charter amendment. For example, this agency problem could take the form of directors unduly beholden to a controlling shareholder (a concern that is typically absent when analogous rights are granted to creditors at arm's length). On the other hand, a contract could simply be a cheaper way to adopt these provisions and one that is less vulnerable to hold-up by other shareholders.

121. For one example of such an argument, see Simone Sepe, Intruders in the Boardroom: The Case of Constituency Directors, 91 WASH. U. L. REv. 309, 312, 315, 337-38 (2013). Sepe argues that certain cash poor firms benefit from being able to trade board control for financing. 


\section{Interactions}

Like the terms of any contract, the terms of shareholder agreements interact. Studying the relationships among these contracts' provisions would be a fertile setting for understanding how and why parties craft governance. ${ }^{122}$ One especially interesting set of interactions will be between horizontal and vertical commitments. For instance, benign voting agreements among minority blockholders may have a less attractive cast if they are accompanied by corporate guarantees to include those designees in the corporate proxy slate.

\section{Controlling Minority Shareholders}

A subset of the vertical agreements take the form of "controlling minority structures"-governance arrangements in which a shareholder exercises control over a firm that is disproportionate to the size of its equity stake. ${ }^{123}$ As an example, a shareholder with a $30 \%$ voting stake may hold the right to nominate the majority of the board, or a shareholder may retain a range of veto rights even when its ownership stake falls to $30 \%$ or $20 \%$ of firm equity.

Under a strong version of the view that IPO governance arrangements are optimal, even these vertical arrangements are desirable. But from an agency cost perspective they are suspect. Controlling minority structures by definition grant the parties involved greater influence over corporate decision-making than what corresponds to the share of cash flows they internalize. ${ }^{124}$ As a result, a party is exercising control, but their incentives to maximize firm performance may be weak and their incentives to consume perquisites of control strong. ${ }^{25}$ Table 7 summarizes this analysis of agency costs.

\section{The Jurisprudence of Shareholder Agreements}

Shareholder agreements raise a host of complex legal questions, almost all of which have been overlooked by the literature. In aggregate, these issues lie at the heart of Delaware's evolving private company

122. For instance, one could ask, "Which control provisions typically are accompanied by transfer restrictions?" Or, "Are veto rights complements or substitutes to director designation rights?"

123. The most familiar of these is dual class stock structures in which a firm issues two classes of common stock with different voting rights.

124. For an example of recent work on the dangers of controlling minority structures, see, for example, Lucian A. Bebchuk \& Kobi Kastiel, The Perils of Small-Minority Controllers, 107 GEO. L.J. 1453 (2019). Bebchuk and Kastiel briefly discuss post-IPO voting agreements in the context of their analysis of multi-class stock. Id. at 1484-85.

125. Another reason to find shareholder agreements less troubling than, say, dual class stock is that the agreements tend to terminate when ownership percentages fall below defined thresholds. 
jurisprudence-the setting in which issues involving shareholder agreements are typically litigated. The case law also guides how courts might resolve issues in the post-IPO shareholder agreements detailed here.

Here, I divide the discussion into questions raised by the vertical and horizontal components of the agreements. The vertical issues involve (1) which commitments by the corporation itself are enforceable, and (2) when shareholders can waive statutory rights by shareholder agreement that the charter could not eliminate. The horizontal issues concentrate on when the parties to a shareholder agreement become a controlling shareholder.

While I do not have the space to fully pursue the issue here, it is worth noting that shareholder agreements arguably pose a profound challenge to the fiduciary architecture of Delaware law. The tapestry of corporate law draws fundamental contrasts - between control rights and contractual rights, between the types of rights held by creditors (generally, promissory, and fixed) and by equity (generally, residual, and discretionary), between internal and external, and ultimately, turning on all of the above, between those who do and do not owe fiduciary duties. It is simple to state why shareholder agreements challenge this picture: they grant significant corporate power to the paradigmatic "internal" patron-shareholders-but in a way that is fixed, external, and contractual, rather than routed through the board. ${ }^{126}$ They thus raise a difficult question: Why do only certain forms of control receive fiduciary scrutiny? ${ }^{\text {27 }}$

\section{A. Vertical Commitments}

\section{Corporate Commitments}

Perhaps the most difficult and interesting issue raised by corporate promises to shareholders involves the corporation committing to support shareholder designees for indefinite periods of time. ${ }^{128}$ Like the corporate grant of veto rights, the agreements sit uneasily with Delaware law because they revise the default allocation of control by placing in the hands of shareholders powers that usually rest with the board. Commitments to support board designees are especially problematic, however, because they go to a core fiduciary obligation of the board and purport to bind the discretion of a future board as well.

126. I dwell on one aspect of this further in Section VI.A.

127. Tentatively, I would suggest that fiduciary analysis should be concerned with the exercise of control when it involves wide-ranging, discretionary, and ongoing influence over corporate decision-making. Where courts have gone wrong is neglecting to see that the ability to influence ongoing firm policy can be established by rights that are at least formally contractual control rights.

128. The phenomenon of a corporation granting control rights by contract is not unknown. Credit agreements often grant creditors robust control rights (which are typically contingent on the corporation violating a contractual commitment), and the debt governance literature carefully studies these provisions and their role in governance. See supra note 117. 
In the annual proxy statement, the board suggests to shareholders that they elect certain persons to the board of directors. In doing so, directors exercise a power that lies at the heart of their fiduciary duties: they must recommend that shareholders elect those persons that the board believes in good faith are best suited to serve as directors on the next board. It is worth emphasizing how important the company's endorsement is for those unfamiliar with corporate elections. Most corporations, most of the time, are one-party states. Shareholders generally vote for the slate of board candidates that the corporation proffers in its proxy statement as the company's suggested slate of candidates. ${ }^{129}$ Now there is no fiduciary issue if, upon due consideration, the board believes that a specific individual is so suited and promises a shareholder to include that person in the corporate slate of candidates for election this year and to use its best efforts to elect her. The doctrinal problem, and it is a serious one, enters when the current board commits to support a shareholder's directorial nominees, without knowing their identity and for indefinite periods of time (typically, for as long as a shareholder retains an equity position exceeding a defined threshold). The shareholder agreements I observe routinely do this, effectively binding the hands of future boards and eviscerating their fiduciary discretion. ${ }^{130}$

An even broader tension stems from the fact that the board of director's authority over corporate affairs is one of the central mandatory features of Delaware law. ${ }^{131}$ A set of seminal Delaware precedents - the stuff of business organizations casebooks - have invalidated various governance devices for improperly infringing on the board's authority. The reach of these precedents cast a shadow of potential unenforceability over provisions like that quoted above. Because each of these cases is somewhat idiosyncratic, it is a shadow, rather than a clear bar.

129. This is especially true in new public companies. The default rule of Delaware law is that the individual elected for a directorship is simply the candidate who gets the most votes (a "plurality" rule). As a result, an individual need not win many votes, if the election is uncontested. Under this circumstance, the imprimatur of the corporation usually results in victory. Many mature public corporations have voluntarily switched to a "majority" rule in which a person is only successfully elected to a directorship if they obtain a majority of votes cast.

130. See, e.g., SolarWinds, Shareholder Agreement $\$ 2.1 .2(\mathrm{c})$; Shake Shack Inc., Stockholders' Agreement § 2.1(b) (Jan. 20, 2015).

131. The starting place for the mandatory role of the board is Section 141(a) of the Delaware General Corporation Law, which declares, "The business and affairs of every corporation . . . shall be managed by or under the direction of a board of directors." In full, the provision continues "except as may be otherwise provided in this chapter or in [the corporation's] certificate of incorporation," but the Delaware jurisprudence seems written as if there was no such caveat. A final caveat is that if a Delaware corporation adopts a board, then Delaware's statutory corporate law and case law establish a set of mandatory aspects to board power. While almost all Delaware corporations have boards, not all do. See DEL. CODE ANN. tit. $8, \S 141$ (a) (2020). 
Quickturn is particularly instructive. ${ }^{132}$ The litigation involved a corporation whose board had adopted a poison pill, but included a provision limiting a newly elected board's ability to remove the pill for one hundredeighty days. The Delaware Supreme Court rejected the enforceability of this delayed redemption feature, noting that "[o]ne of the most basic tenets of Delaware corporate law is that the board of directors has the ultimate responsibility for managing the business and affairs of a corporation." 133 Although the pill limited the board's power in "only one respect," it concerned "an area of fundamental importance to shareholders-negotiating a possible sale of the corporation." ${ }^{134}$ Echoing a prior court, it concluded that " $[\mathrm{t}] \mathrm{o}$ the extent that a contract, or a provision thereof, purports to require a board to act or not act in such a fashion as to limit the exercise of fiduciary duties, it is invalid and unenforceable." 135

Another example is CA, Inc. V. AFSCME Employees' Pension Plan, ${ }^{136}$ in which shareholders proposed to add a corporate bylaw that would require the company to reimburse reasonable expenses of insurgent candidates. In a controversial ruling (later overturned by statute), the Delaware Supreme Court held that the shareholder proposal was invalid because it improperly interfered with the powers of the board. ${ }^{137}$ Specifically, the shareholders in AFSCME proposed an amendment such that the board "shall cause the corporation to reimburse a stockholder or group of stockholders (together, the 'Nominator') for reasonable expenses ('Expenses') incurred in connection with nominating one or more candidates in a contested election of directors to the corporation's board of directors."138 The Supreme Court held that this improperly limited the director's "exercise [of] their fiduciary duty to decide whether or not it would be appropriate, in a specific case, to award reimbursement." 139 These precedents leave corporate commitments to support shareholder nominees in a kind of legal limbo; their enforceability is unclear.

\footnotetext{
132. Quickturn Design Sys., Inc. v. Shapiro, 721 A.2d 1281 (Del. 1998).

133. Id. at $1291 ; i d$. at 1292 ("Section 141 (a) . . confers upon any newly elected board of directors full power to manage and direct the business and affairs of a Delaware corporation.").

134. Id. at 1291.

135. Id. (quotation marks and citations omitted).

136. 953 A.2d 227 (2008); id. at 231 ("[T]he DGCL has not allocated to the board and the shareholders the identical, coextensive power to adopt, amend and repeal the bylaws.").

137. Id. at 230 .

138. Id.

139. Id. at 240 .
} 


\section{How Many of Shareholders' Statutory Rights Can Shareholder Agreements Waive?}

How many of a shareholder's statutory rights may she waive by contract? More broadly, how far may contract go in displacing otherwise mandatory shareholder rights? Delaware law offers no definitive answer to these questions, but recent case law suggests the answer is that contract may go quite far indeed.

For example, in Manti Holdings, LLC V. Authentix Acquisition Co., ${ }^{140}$ the Delaware Chancery Court held that shareholders are bound by their waiver of their statutory appraisal rights in a shareholder agreement. ${ }^{141}$ Statutory appraisal rights, it seems, can be waived by contract. Bonanno $v$. $V T B$ Holdings, Inc. ${ }^{142}$ addressed shareholders' statutory rights under Section 115 of the DGCL. Section 115 authorizes a corporation's certificate of incorporation or bylaws to require that internal corporate claims are brought exclusively in Delaware. It also and prohibits the charter and bylaws from barring shareholders from bringing internal corporate claims in Delaware. The Chancery Court held that Section 115 does not restrict waiving that right in a shareholder agreement. ${ }^{143}$ The court reasoned that Section 115 does not alter Delaware's general public policy favoring contractual freedom. It noted that the bill's synopsis suggested that the legislature did not intend "to prevent the application of [a] provision in a stockholders agreement or other writing signed by the stockholder against whom the provision is to be enforced."144

The Chancery Court's opinion in Kortum v. Webasto Sunroofs, Inc. ${ }^{145}$ suggests that a shareholder agreement might be used to shut down an important tool of contemporary litigation. There, the court addressed a director and shareholder's rights under Section 220 of the DGCL to inspect a corporation's books and records. ${ }^{146}$ In Kortum, the Chancery Court found that the terms of the shareholder agreement required the provision of certain information, but did "not contractually limit the information that must be provided . . . , nor [did the agreement] expressly provide for a waiver of statutory inspection rights under $\S 220$." However, the court, added, suggestively, that "[t]here can be no waiver of a statutory right

\footnotetext{
140. C.A. No 2017-0887-VCSG (Del. Ch. Oct. 12, 2018).

141. The decision is carefully limited to its facts.

142. 2016 WL 614412, at*15 (Del. Ch. Feb. 8, 2016).

143. Id.

144. Id. (quoting S. 75 syn., 148th Gen. Assemb. § 5 (Del. 2015) (“Synopsis")).

145. 769 A.2d 113, 125 (Del. Ch. 2000).

146. That right is phrased in conspicuously mandatory terms in the DGCL. See DEL.
} CODE ANN. tit. 8, § 220 (2020). 
unless that waiver is clearly and affirmatively expressed in the relevant document." 147

Finally, Sections 109(b) and 102(f) of the DGCL prohibit the bylaws or charter, respectively, from requiring that fees be shifted in litigation asserting internal corporate claims. The legislative commentary accompanying the amendments to the DGCL adopting these provisions expressly notes that shareholder agreements are not subject to their prohibitions. ${ }^{148}$

Both court opinion and legislative commentary thus suggest that shareholders can waive a panoply of corporate statutory rights, including the right to an appraisal, the right to litigate internal corporate claims in Delaware, the right to inspect corporate books and records (albeit, in dicta), and the prohibition on fee shifting. Through a shareholder agreement, many of the favored tools of contemporary corporate litigants could be defanged. Is this a desirable policy result, and if so, why? Developing a full analysis of this would require another paper, ${ }^{149}$ but I think one thing is clear: "mandatory" corporate law turns out to be a trickier concept than it first appears. Certain rules are mandatory, but only for the charter and bylaws, not shareholder agreements; some rules bind all three. It leaves the question of how much of what we have taken to be mandatory corporate law is waivable by shareholder contract?

\section{B. Horizontal Commitments: Of Contract, Controlling Shareholders, and Fiduciary Duties}

The deepest doctrinal questions raised by shareholder agreements may lie in how they contractualize the nature of corporate control. As a general matter, Delaware's jurisprudence sharply distinguishes between the exercise of contractual rights, which subject the holder to no fiduciary duties, and control over the board, which does. Because they layer contracts over the firm's internal politics, shareholder agreements lie at the division between controlling shareholder status and mere contractual rights.

147. 769 A.2d at 125; see also Matter of Appraisal of Ford Holdings, Inc. Preferred Stock, 698 A.2d 973, 976 (Del. Ch. 1997) (suggesting that preferred stockholders could waive their appraisal rights through a shareholder agreement).

148. S. 75 syn., 148th Gen. Assemb. $\S \$ 2,3$ (Del. 2015) (noting that neither Section 109(b), nor Section 102(f) was "intended ... to prevent the application of such provisions pursuant to a stockholders agreement or other writing signed by the stockholder against whom the provision is to be enforced").

149. Indeed, Jill Fisch has offered a vigorous and illuminating critique of Manti and the line of reasoning it suggests. Fisch, supra note 33. Fisch's analysis turns on several factors, including the ability of shareholder agreements to undermine the universality and certainty of corporate law. 


\section{Collective Controlling Shareholders}

When shareholders contract with each other over their control rights they raise a core question for corporate law: when does a coalition of coordinating shareholders form a (collective) controlling shareholder? When, if ever, do the signatories to a shareholder agreement owe other shareholders fiduciary duties? These were the questions faced by the Delaware Supreme Court two years ago in Sheldon v. Pinto. ${ }^{150}$

In principle, Delaware law can conceptualize several separate shareholders as together acting as a controlling shareholder. ${ }^{151}$ If multiple stockholders together exercise "majority or effective control" then "each member [is] subject to the fiduciary duties of a controller." 152 To prove that shareholders form a controlling shareholder it is necessary to show they are "connected in some legally significant way-such as by contract, common ownership, agreement, or other arrangement - to work together toward a shared goal." 153 The difficulty lies in applying this logic to the factually thorny setting of shareholder agreements.

In Sheldon v. Pinto, the key issue was whether the signatories of a shareholder agreement constituted a controlling shareholder. ${ }^{154}$ The defendants together controlled sixty percent of the corporation's voting power and were signatories of a voting agreement granting them the right to appoint three directors, who then chose two additional directors. These five directors were the vast majority of the board. The shareholders had invested together in other businesses before and had acted together to establish a financing arrangement that the plaintiffs claimed had unfairly diluted them. Recent Chancery Court decisions addressing broadly similar facts had come out in both directions. ${ }^{155}$

150. Sheldon v. Pinto Tech. Ventures, L.P., No. 81, 2019, 2019 WL 4892348, at *4 (Del. Oct. 4, 2019).

151. There are two ways to be a controlling shareholder under Delaware law. Id. The first and simplest is if a shareholder owns more than fifty percent of the voting power of a corporation. $I d$. The second is if a shareholder owns less than fifty percent, but "exercises control over the business affairs of the corporation." In re KKR Fin. Holdings LLC S'holder Litig., 101 A.3d 980, 991 (Del. Ch. 2014). Control over the affairs of a corporation can exist generally or with respect to a specific transaction. In re Tesla Motors Stockholder Litig., 2018 WL 1560293, at*13 (Del. Ch. Mar. 8, 2018) (citing other cases on this point).

152. Sheldon, 2019 WL 4892348, at *4.

153. Id. A legally significant connection is more than a "mere concurrence of self-interest among certain stockholders." Carr v. New Enter. Assocs. Inc., 2018 WL 1472336, at *10 (Del. Ch. Mar. 26, 2018). Instead, there must be evidence of an "actual agreement," although formality or something in writing is unnecessary. In re Crimson Expl. Inc. S'holder Litig., 2014 WL 5449419, at *15 (Del. Ch. Oct. 24, 2014).

154. 2019 WL 4892348, at *4.

155. See van der Fluit v. Yates, No. CV 12553-VCMR, 2017 WL 5953514, at *5 (Del. Ch. Nov. 30, 2017); In re Hansen Med., Inc. Stockholders Litig., No. 12316-VCMR, 2018 WL 3030808 (Del. Ch. June 18, 2018). 
The Delaware Supreme Court found that there was no controlling shareholder. Its logic, however, was thin. It held that the allegations "fail to allege with reasonable conceivability that the Venture Capital Firms were connected in a 'legally significant' way" at any time. This is despite the fact that the venture capital firms were parties to a shareholder agreement that guaranteed they designated almost the entire board of directors. The motivation for the court's decision seems to have been that the appointment of directors was just a separate issue from the financing transaction. ${ }^{156}$

It is tempting to think there is a simple answer that the Delaware Supreme Court missed. The easiest bright-line rules, however, will not work. Consider a strict rule that the signatories to a shareholder agreement are members of a collective controlling shareholder and thus owe fiduciary duties. In many private companies, every shareholder is a party to the corporation's shareholder agreement. Treating all the signatories as forming a controlling shareholder would thus mean that none of them owed each other fiduciary duties (because they compose the controlling shareholder). It would make shareholders' fiduciary duties largely disappear. Thus, equating membership in a shareholder agreement with forming a controlling shareholder cannot work. Yet, treating participation in a shareholder agreement as never forming a controlling shareholder is clearly wrong. For instance, an agreement that required signatories to always vote together in specific ways in directorial elections and on any other matter of consequence would surely form a controlling shareholder.

I believe an alternative approach would better serve corporate law by more closely tracking the actual exercise of corporate power. First, consider an analogy that may be clarifying: corporations in which members of a founding family together hold over $50 \%$ of the voting power. Here, too, there is a delicate question of whether, in any particular instance, the family members are a collective controlling shareholder. This is a helpful comparison for the parties to a voting agreement. Family members can have a falling out and be at odds with each other despite a history of cooperation. The fact that they are family members does not guarantee they have agreed to run the firm together. Nonetheless, the right starting point for thinking about three siblings who each own $20 \%$ of a corporation's shares is surely to presume that they form a collective controlling shareholder. Similarly, the better approach for courts is to adopt a rebuttable presumption that any shareholders with the right to designate a director pursuant to a voting

156. Pinto, 2019 WL 4892348, at *6 ("The Voting Agreement, which bound all of IDEV's shareholders, was unrelated to the 2010 Financing and Abbott acquisition, and only governs the election of certain directors to the IDEV board."); id. ("TThe Venture Capital Firms' appointment of directors 'does not, without more, establish actual domination or control."' (quoting Williamson v. Cox Commc'ns, Inc., 2006 WL 1586375, at*4 (Del. Ch. June 25, 2006))). 
agreement together form a controlling shareholder, if the voting agreement aggregates substantial voting power (say over 35\%) and forms the largest voting bloc in a corporation's elections. ${ }^{157}$ To rebut this presumption, shareholders would have to show that the parties affirmatively acted contrary to each other's interests.

This approach builds on a truth Pinto ignores. A voting agreement among three twenty-percent blockholders, where each nominates two directors to a six- or nine-person board, is a projection of power into the future in which the shareholders and their director designees not only block the arrival of any other controlling shareholder, but cooperatively determine the composition of the board. This does not guarantee joint commitment to every underlying policy decision, but demanding such a commitment ignores the fact that determining who will make decisions already massively influences those outcomes.

Under this alternative approach, the defendants in Pinto would have been presumed to be a controlling shareholder. The defendants would have had to rebut this presumption by showing that they acted in conflicting ways. Based on the opinion, this would have been a difficult challenge for those parties to meet. The decision would presumably have come out in the opposite way. ${ }^{158}$

157. The signatories to a voting agreement would not be included in the collective controlling shareholder; only parties whose nominees were the object of the agreement. The reason to require a substantially sized block as well as high voting power is that the largest block could, at least in principle, amount to a small size (e.g., five percent) insufficient to sway an election.

158. A related but distinct problem for the court is deciding when a minority shareholder constitutes a controlling shareholder because of other relevant facts and circumstances. The extensive contractualization of control implemented in some shareholder agreements makes this an especially important and fraught inquiry. In recent years, the Delaware courts have had a small docket of cases dealing with this issue of whether a minority shareholder can be a controlling shareholder where she enjoys particular powers, such as potent contractual rights. See, e.g., Corwin v. KKR Fin. Holdings LLC, 125 A.3d 304 (Del. 2015); FrontFour Capital Grp. v. Taube, 2019 WL 1313408 (Del. Ch. Mar. 22, 2019); In re Tesla Motors Stockholder Litig., 2018 WL 1560293, at *9 (Del. Ch. Mar. 8, 2018); Basho Techs. Holdco B v. Georgetown Basho Inv'rs, 2018 WL 3326693 , at *26-27 (Del. Ch. July 6, 2018). For a provocative discussion of these cases and related issues, see Lipton, supra note 104. One other major governance concern is raised by voting agreementswhy exactly are they not a form of unlawful vote buying? A voting agreement commits one shareholder's votes to the directorial nominee of another shareholder without transferring the cash flows or ownership of the underlying shares; it contracts away a share's vote but nothing else. The leading case on vote buying, Schreiber v. Carney, 447 A.2d 17 (Del. Ch. 1982), defines vote buying as a commitment to vote "supported by consideration personal to the stockholder, whereby the stockholder divorces his discretionary voting power and votes as directed by the offeror." Id. at 23. Vote buying, however, is not illegal per se, provided its object is not to defraud or disenfranchise other shareholders. Instead, "each arrangement [involving the transfer of stock without the transfer of ownership] must be examined in light of its object or purpose." Id. at 25. Under Schreiber, pure horizontal voting agreements seem clearly permissible, but if the corporation's directors are involved in pressuring parties to enter voting agreements, the courts' analysis would be significantly more complex. See Crown EMAK Partners, LLC v. Kurz, 992 A.2d 377, 387 (Del. 2010); Williams v. Ji, C.A., No. 12729-VCMR, slip op. at 18-20 (Del. Ch. June 28, 2017); Portnoy v. Cryo-Cell Int'l, Inc., 940 A.2d 43, $73-76$ (Del. Ch. 2008). It is also worth noting that there are important issues regarding the relationship between voting agreements and the extensive empty 


\section{The Bigger Picture}

In this last Part, I raise some of the implications of shareholder agreements for broader questions in corporate law without making any pretense to settle the debates involved.

\section{A. What Is Control?}

The conception of corporate control that pervades much of the literature is anemic, amounting to the view that shareholders appropriate the "residual rights of control" and those rights alone. ${ }^{159}$ That conception views shareholders as bargaining for ongoing authority over discretionary firm decisions that have not been reduced to contract; they then delegate that authority to the board of directors. Other stakeholders of the firm, in contrast, secure their rights against the firm by contract.

As is by now clear, this conception is impoverished and misses much of the complexity of actual practice. Shareholders can and do use extensive contractual technologies to secure their control rights. The standard conception is more like a special case of a richer conception of control; it applies best to the subset of public companies in which shareholders possess no or few rights beyond those granted by the default rules of law. Control has at least two dimensions - residual control exercised directly through voting or the board and contractual control rights.

This raises questions for the literature along two fronts. First, the picture of governance in which providers of financing bargain for distinct types of rights is incomplete. It is tempting to think that the efficient course of action for firms is to grant some of the providers of financing rights over the exercise of discretion (i.e., as corporate law grants voting rights to shareholders) and to others contractual rights (i.e., as credit agreements create for creditors), but not to mix the two. Shareholder agreements do exactly that, however, conferring on shareholders who possess residual rights of control a range of contractual control rights reminiscent of those granted creditors, such as veto rights over major corporate transactions. What about the setting in which these agreements are entered makes combining contractual and discretionary control rights plausible where elsewhere they are not?

Second, the distinction between contract and authority is neither as robust, nor as important, as it is often taken to be. The distinction between

voting literature. See, e.g., Henry T.C. Hu \& Bernard S. Black, The New Vote Buying: Empty Voting and Hidden (Morphable) Ownership, 79 S. CAL. L. REV. 811 (2006).

159. For an example of an important exception, see Bernard Black, Corporate Law and Residual Claimants (Stanford Law \& Econ. Olin Working Paper No. 217, 2009), https://ssrn.com/abstract=1528437 [https://perma.cc/UCU8-DVVM]. 
rights over corporate decisions that are granted by contract and in the form of discretionary authority forms a major fault line in Delaware corporate jurisprudence. Under Delaware law, shareholders who influence the corporation's affairs by controlling the board are controlling shareholders with fiduciary duties, while shareholders who simply wield contractual rights to influence the board are not. ${ }^{160}$

The veto rights granted shareholders add on to the pressure already placed on the distinction between contract and authority by the covenantbased contractual rights granted creditors. In credit agreements, creditors are often granted a contingent form of the veto rights granted in shareholder agreements. Indeed, creditors are often given more extreme rights to force corporations in breach of covenants into liquidation. If a company violates a financial covenant, by say, failing to maintain the operating cash flow numbers specified in a credit agreement, a creditor can demand immediate repayment, which will often lead to bankruptcy proceedings. It is widely acknowledged that creditors rarely do this; instead, creditors use the inducement of waiving the violation to renegotiate the terms of the credit agreement and the structure of the company's governance. ${ }^{161}$ The function of at least some contract-based rights is to obtain leverage over the board's exercise of authority. At this point, the distinction might still be clear-covenants are a kind of contingent version of gaining authority and this fits with the general understanding of creditors as fixed claimants who become residual claimants when a firm is in financial distress or insolvency.

Imagine, though, that a corporation grants an investor a veto right over every material decision that the board of directors makes. Is it still useful to distinguish ongoing authority and discretion from this contractual right?

The example is not as fanciful as it might seem. The Stockholders Agreement of Moelis \& Company grants a list of veto powers that begins with the routine but goes on to include a designated shareholder's ability

160. See, e.g., Calesa Assocs., L.P. v. Am. Capital, Ltd., No. CV 10557-VCG, 2016 WL 770251, at*11 (Del. Ch. Feb. 29, 2016); Thermopylae Capital Partners v. Simbol, Inc., 2016 WL 368170, at*14 (Del. Ch. Jan. 29, 2016) ("[A] stockholder who-via majority stock ownership or through control of the board-operates the decision-making machinery of the corporation, is a classic fiduciary .... Conversely, an individual who owns a contractual right, and who exploits that right - even in a way that forces a reaction by a corporation - is simply exercising his own property rights, not that of others, and is no fiduciary.").

161. See, e.g., Douglas G. Baird \& Robert K. Rasmussen, Private Debt and the Missing Lever of Corporate Governance, 154 U. PA. L. REV. 1209 (2006); Greg Nini, David C. Smith \& Amir Sufi, Creditor Control Rights, Corporate Governance, and Firm Value, 25 REV. FIN. STUD. 1713, 1758 (2012). As noted, granting such operational rights to shareholders also raises questions about the legal limits and normative desirability of the director primacy, centralized management, and delegation typical of public firms. See, e.g., Stephen M. Bainbridge, Director Primacy: The Means and Ends of Corporate Governance, 97 Nw. U. L. REV. 547 (2003) (offering a seminal defense of directorial authority in corporate governance). 
to veto (or approve) every "material contract" the board is considering approving. ${ }^{162}$ The higher the list of consent rights is stacked, the more contract seems to converge with authority. That of course does not mean contract and authority are the same thing, but it does suggest that what control is ultimately about - and our best conception of it - may be something that is not reducible to either contract or authority.

\section{B. What Is Public Company Governance?}

In recent years, the almost century's old public/private divide in securities law has come under immense pressure. ${ }^{163}$ One prominent source of dissatisfaction is the current state of public company governance, and particularly the public company board and its emphasis on independent directors. ${ }^{164}$ Recently, scholars have argued vigorously for alternative models of public company governance, such as the promise of a "Board 3.0," inspired, in part, by the boards of private equity portfolio companies. ${ }^{165} \mathrm{Un}$ der this model of a corporate board, directors would be highly informed, well-resourced, and strongly motivated to monitor management's operational skill and performance, in contrast to a board more focused on monitoring management for misconduct, which is common in public companies today. The directors of corporations with such a governance model could hold closer ties to long-term, but not necessarily controlling, shareholders. For this debate, post-IPO firms with shareholder agreements offer a potentially fecund laboratory for study. A significant subset of these firms remain controlled by their pre-IPO shareholders, which-through their shareholder agreements - continue to maintain many of the governance features, like veto rights and contractualized boards, paradigmatic of private company governance. They are, in a sense, close corporations afloat in the public equity markets, a kind of public/private governance hybrid, and perhaps one illustration of Board 3.0.

162. Moelis \& Co., Stockholders Agreement (Mar. 24, 2014) ("[T]he Board shall not authorize, approve or ratify any of the following actions or any plan with respect thereto without the prior approval ... the entry into or material amendment of any Material Contract ...."). A material contract is designed to include every contract that would qualify as a material contract under Item 601(b)(10) of Regulation S-K as well as a number of other types of contracts.

163. See, e.g., Elisabeth de Fontenay, The Deregulation of Private Capital and the Decline of the Public Company, 68 Hastings L.J. 445 (2017); Michael Ewens \& Joan Farre-Mensa, The Deregulation of the Private Equity Markets and the Decline in IPOs, 33 REV. FIn. STUD. 5463 (2020).

164. See, e.g., Ronald J. Gilson \& Jeffrey N. Gordon, Board 3.0, 74 BUS. LAw. 351

165. Id. at $358-61$. 


\section{What Is Governance?}

The law treats the charter and bylaws, on one hand, and the shareholder agreement, on the other, quite differently. Why? A doctrinalist might appeal to the status of each under statutory law-each is covered by one or more provisions that partly determine its metes and bounds. Yet, as recent case law has demonstrated, extant doctrine pervasively underdetermines how courts should answer a variety of questions about shareholder agreements (as well as the charter and bylaws). ${ }^{166}$

Here, I approach courts' distinct treatment of the instruments based on how private law theory has articulated the distinction between property and contract. Although debate continues, a core insight is that a key difference between a property right and a contract right is that "a property right is enforceable, not just against the original grantor of the right, but also against other persons to whom possession of the asset, or other rights in the asset, are subsequently transferred. . . . the burden of a property right "runs with the asset."'167 A contractual right, by contrast, binds only the parties that originally agreed to the bargain. ${ }^{168} \mathrm{~A}$ key question is thus whether a voluntary arrangement entered into by two (or more) parties concerning an asset will bind third parties who come to own that asset or have rights as to it.

Henry Hansmann and Reinier Kraakman have argued that the property/contract distinction is driven by the degree of notice that it is socially desirable to offer downstream parties. By giving greater leeway to shareholder agreements, Delaware's courts seem to implicitly adopt this view that where greater notice is given - that is, when a contract rather than the charter is used-more freedom can be granted shareholders to craft governance. Their logic is clearer if one steps back to the private company context, which is typically the setting in which Delaware courts adjudicate disputes involving shareholder agreements. For the shareholders of a private company, notice can differ significantly depending on whether a term

166. See, e.g., Ark. Teacher Ret. Sys. v. Alon USA Energy, Inc., No. CV 2017-0453KSJM, 2019 WL 2714331 (Del. Ch. June 28, 2019) (addressing whether a shareholder agreement is enforceable by nonparties under third party beneficiary doctrine); Caspian Select Credit Master Fund Ltd. v. Gohl, No. CV 10244-VCN, 2015 WL 5718592 (Del. Ch. Sept. 28, 2015) (addressing whether a shareholder agreement can be specifically enforced).

167. Henry Hansmann \& Reinier Kraakman, Property, Contract, and Verification: The Numerus Clausus Problem and the Divisibility of Rights, 31 J. LEgAL STUD. S373, S378 (2002); see also id. at S374 ("[A] property right in an asset, unlike a contract right, can be enforced against subsequent transferees of other rights in the asset... . [A] property right runs with the asset."); Thomas W. Merrill \& Henry E. Smith, What Happened to Property in Law and Economics?, 111 YALE L.J. 357, 360-64 (2001). While scholars remain divided between Hansmann and Kraakman and Merrill and Smith's views, both draw a strong contrast between contractual and property rights.

168. Contract law's doctrines of assignment and delegation, if appropriate, allow properly transferred contract rights to bind a transferee, but those doctrines require a transferee to be on notice of the rights or duties involved. 
is contained in a charter or shareholder agreement. Shareholders are directly bound by charter terms regardless of whether they know of or personally assented to it. On the other hand, shareholders are directly bound by a shareholder agreement only if they entered into the contract.

The central instruments of corporate governance thus fall on different sides of the property/contract distinction, and the fact that they do so offers a powerful functional justification for the differences in the law's treatment of them, which might otherwise seem ad hoc. The charter and bylaws bind nonparties, and provisions established by those agreements generally "run with the asset" of stock ownership. A purchaser of low-vote Alphabet stock will simply be ignored if he complains that the Alphabet founders (perhaps surprisingly) own little of the company's cash flows but hold highvote stock granting them an impregnable position of control. You simply do not need to know what the charter says for your rights in a corporation to be determined by its lawful contents. The bylaws too, while more cabined in scope, alter nonconsensually the rights of shareholders. In contrast, the shareholder agreement binds the signatories to it, and generally does not bind nonparties at all. It is an actual contract, and just that. Table 8 summarizes various property- and contract-like features of different forms of governance.

So, is corporate governance a matter of property or contract? It seems to be both. A shareholder's rights run with transfer of the stock when they are charter-based rights, and they do not run with transfer when they are shareholder agreement-based rights. The charter and bylaws are propertylike and bind nonparties, while a contractual overlay that does not bind nonparties can be imposed on top. In some respects, the law here fits elegantly with theory: courts largely treat contracts as imposing obligations only on signatories and, because of that, allow contracts to go further in altering otherwise mandatory rules than it does the charter or bylaws. The limits of freedom of design on these instruments track parties' knowledge of changes and the directness of their consent to them. Courts take seriously the different strains of voluntariness represented by direct consent to a contract versus being constructively put on notice of the terms of a corporation's charter when one purchases a stock.

In one respect, though, the fit is uneasy, and that is when corporations grant veto rights, commitments to support board designees, or other such rights to specific shareholders by contract. These rights do directly affect nonparty shareholders. Shareholders can no longer sell a corporation, for instance, if a minority shareholder possesses a veto right over a change of control. And in a private firm they may have no notice of the loss of that right if it was established by contract (albeit, one to which the corporation was a signatory). Bilateral corporate-shareholder undertakings, or vertical 
commitments, may not offer the right kind of notice for the consequences they can impose. ${ }^{169}$

In any event, I am not trying to answer where the nature of the firm lies in the property/contract architecture, but to emphasize that the pervasive use of contract to structure control puts pressure on our inherited conceptions of corporate governance.

\section{Conclusion}

This Article addresses the role of shareholder agreements in law, theory, and practice. They emerge in the modern case law as a distinctively contractual form of corporate governance that allow shareholders to craft the basic terms of exit, voice, and liability. Most importantly, shareholders use them to directly assign control rights-from directorships, to veto rights - by contract, unwinding the default allocation of control created by statutory corporate law.

I explore the function of shareholder agreements empirically by studying their use in new public companies. They provide a rich universe for study and one that raises questions along a host of dimensions. In particular, these agreements undermine some of corporate law's foundational distinctions - between control rights and contractual rights, between the types of rights held by creditors (generally, promissory, and fixed) and by equity (generally, residual, and discretionary), between internal and external, and ultimately, between who owes and who is entitled to fiduciary protection. They suggest the need for richer conceptions of control and of corporate governance.

169. This analysis also suggests that it is somewhat misleading to think of a security, like a preferred stock or common stock, as an ordinary contract. It is not, since its rights can be nonconsensually altered by charter. 
The Separation of Voting and Control

\section{List of Tables}

Table 1: Control Rights over the Board

Table 2: Veto Rights

Table 3: State of Incorporation for IPO Firms 2013-2018

Table 4: Industry Distribution for IPO Firms 2013-2018

Table 5: New Public Firms Subject and Not Subject to Shareholder Agreements

Table 6: Summary Statistics on Control Sharing Firms

Table 7: Agency Costs in Shareholder Agreements

Table 8: Governance - Between Property and Contract

Table 1: Control Rights over the Board

\begin{tabular}{lll}
\hline Control Feature & Incidence & $\begin{array}{l}\% \text { of SAs } \\
(N=139)\end{array}$ \\
\hline Board nomination rights & 118 & $85 \%$ \\
Corporate support & 98 & $72 \%$ \\
Inclusion in corporate proxy slate & 79 & $57 \%$ \\
Corporate efforts to elect & 73 & $53 \%$ \\
Voting agreement & 71 & $51 \%$ \\
\hline
\end{tabular}


Table 2: Veto Rights

Negative Covenants Granted Shareholders $(N=50(36 \%))$

Corporate transaction

Entering merger, sale of all assets, or other change of control

Hiring or firing the CEO

Amending the charter or bylaws

Changing nature of business or adding new line of business

Making material acquisitions

Entering a joint venture

Incurring material indebtedness

Entering liquidation or voluntary bankruptcy proceedings

Changing the size of the board

Issuing material new equity

Making dividends or distributions

Entering related party transactions

Resolving material litigation

Average number of above vetoes granted
Incidence of veto

$53 \%$

$35 \%$

$33 \%$

$24 \%$

$42 \%$

$22 \%$

$36 \%$

$38 \%$

$38 \%$

$40 \%$

$18 \%$

$15 \%$

$11 \%$

4

Table 3: State of Incorporation for IPO Firms 2013-2018

\begin{tabular}{lll}
\hline State & SA Adopters & Nonadopters \\
\hline Delaware & $95 \%$ & $83 \%$ \\
Maryland & $0 \%$ & $8 \%$ \\
Nevada & $2 \%$ & $1 \%$ \\
Texas & $0 \%$ & $2 \%$ \\
California & $0 \%$ & $0 \%$ \\
New York & $0 \%$ & $0 \%$ \\
Florida & $0 \%$ & $0 \%$ \\
\hline
\end{tabular}


Table 4: Industry Distribution for IPO Firms 2013-2018

\begin{tabular}{lll}
\hline Industry & $\begin{array}{l}\text { Shareholder } \\
\text { Agreement }\end{array}$ & No Agreement \\
\hline & $N=120$ & $N=714$ \\
Computer & $11.67 \%$ & $14.85 \%$ \\
Programming & & \\
Biological Products & $5.00 \%$ & $26.75 \%$ \\
Oil and Gas Field & $2.50 \%$ & $0.56 \%$ \\
Services & & \\
Pharmaceuticals & $2.50 \%$ & $6.16 \%$ \\
Eating Places & $4.17 \%$ & $0.84 \%$ \\
Commercial Banks & $4.17 \%$ & $5.46 \%$ \\
Investment Advice & $3.13 \%$ & $0.42 \%$ \\
Other & $66.86 \%$ & $44.96 \%$ \\
Total & $100 \%$ & $100 \%$ \\
\hline
\end{tabular}

Table 5: New Public Firms Subject and Not Subject to Shareholder Agreements

\begin{tabular}{llllllll}
\hline & Nonadopters & \multicolumn{5}{c}{ Adopters } & \\
\hline Variable & $N$ & Mean & $\sigma$ & $N$ & Mean & $\sigma$ & Difference in means \\
Market & 650 & 1091.25 & 2338.64 & 111 & 2228.80 & 2991.75 & $-4.53(0.00)^{* * *}$ \\
Value & & & & & & & \\
Total Assets & 468 & 1474.71 & 7530.14 & 78 & 1866.91 & 5160.38 & -0.44 \\
Intangible & 704 & 199.36 & 1038.06 & 118 & 972.74 & 1839.27 & $-6.56(0.00)^{* * *}$ \\
Assets & & & & & & & \\
Total Debt & 705 & 387.17 & 2388.42 & 120 & 1277.71 & 2781.59 & $-3.68(0.00)^{* * *}$ \\
Cash & 710 & 163.83 & 832.95 & 120 & 192.01 & 533.88 & -0.36 \\
\hline
\end{tabular}

This table separately reports statistics for five firm-level financial characteristics for companies that went public between 2013-2018 (the number of observations reflect the data available from Compustat) for firms that went public without a shareholder agreement and those that went public subject to one. It also presents t-tests of the difference of means between those two subsets of firms. The p-values are reported in parentheses for two-sided ttests with unequal variances. Statistical significance is denoted at the $10 \%$ $(*), 5 \%(* *)$, and $1 \%(* * *)$ levels. 
Yale Journal on Regulation

Table 6: Summary Statistics on Control Sharing Firms

\begin{tabular}{lll}
\hline Status & $\begin{array}{l}\text { Voting Agreement } \\
(N=53)\end{array}$ & $\begin{array}{l}\text { No Voting Agreement } \\
(N=529)\end{array}$ \\
\hline $\begin{array}{l}\text { Controlled } \\
\text { Company }\end{array}$ & $79 \%(42)$ & $27 \%(116)$ \\
Not Controlled & $21 \%(11)$ & $78 \%(413)$ \\
$\begin{array}{l}\text { Controlled } \\
\text { Minority Firm }\end{array}$ & $32 \%(17)$ & $5 \%(28)$ \\
\hline
\end{tabular}

Table 7: Agency Costs in Shareholder Agreements

\begin{tabular}{llll}
\hline $\begin{array}{l}\text { Shareholder } \\
\text { Agreements }\end{array}$ & Management & Control Costs: & Control Costs: \\
Costs & Parties & Nonparties \\
\hline $\begin{array}{l}\text { Horizontal Agreements Low } \\
\text { Vertical Agreements }\end{array}$ & Low & -- & Low/Medium \\
$\begin{array}{l}\text { Controlling Minority } \\
\text { Structures }\end{array}$ & Low & Medium & High \\
\hline
\end{tabular}


The Separation of Voting and Control

Table 8: Governance - Between Property and Contract

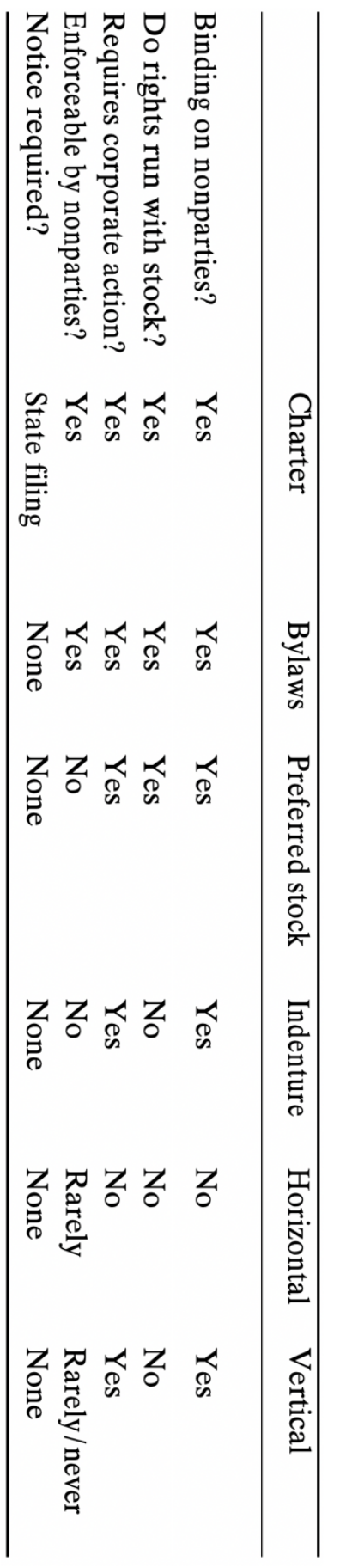

